CUPAUAM 25.2, 1999, pp. 193-250

\title{
EL YACIMIENTO ARQUEOLÓGICO DE EL SAUCEDO (TALAVERA LA NUEVA, TOLEDO): BALANCE Y PERSPECTIVAS
}

\author{
Aguado, M.; Castelo, R.; Torrecilla, A. \\ Universidad Autónoma de Madrid \\ Arribas, R.; Jiménez, O.; López, A.; Sierra, C.; Taléns, C. \\ Arqueólogos
}

\section{Resumen}

En este artículo presentamos una síntesis de los trabajos de investigación, conservación y difusión realizados en el yacimiento de El Saucedo hasta el presente, así como un esbozo de los planes de actuación para el futuro.

\section{Summary}

In this article we present an updated summary of the investigation, preservation and difussion works carried out in the site El Saucedo, as well as the main line to follow in the future regarding to the working plan.

\section{UBICACIÓN}

El enclave arqueológico de El Saucedo, situado en el Conventus Emeritensis, se encuentra en la vega derecha del Tajo junto a Talavera la Nueva (Toledo) y a unos $5 \mathrm{~km}$. aguas abajo de Talavera de la Reina, antigua Caesarobriga. Próxima a la vía de comunicación que unía Caesar Augusta y Emerita Augusta, forma parte de un conjunto de propiedades más amplio que se extiende a lo largo de la vega del Tajo: Vegas de Puebla Nueva; Rielves, Las Tamujas; Vega Baja; Cabañas de la Sagra; Vega de Santa María; Mesegar, todas ellas conocidas a través de noticias y datos arqueológicos (Ramos y Durán, 1988, 237-242). A éstos ejemplos tenemos que añadir otros enclaves aún no estudiados como La Alcoba, Torrejón de Calera, Lorbiga y Los Caños. 
Los textos antiguos que hacen referencia a la ubicación del yacimiento han sido estudiados y publicados por la Dra. Canto $(2001,111)$.

\section{HISTORIA DE LAS INVESTIGACIONES}

Desde el siglo XVI hay noticias antiguas de hallazgos en todo el área, especialmente monedas, cerámica y fragmentos de mármoles. Entre los hallazgos más significativos esta el referido a un ara, dada a conocer por J. Cornide en 1796, aunque fue hallada y descrita por el fraile Ajofrín. El padre Fita cita los numerosos 'materiales arqueológicos hallados en aquella época, como pendientes de oro, un busto togado en mármol, sepulturas, molduras de mármol y monedas de cobre (Canto, 2001, 113-117).

En 1959 el dueño de la finca D. Eugenio Manzano, construyó, junto al camino de servidumbre que la atraviesa, un pozo y una casa de labor (hoy todavía en pie) en la que se emplearon diversos materiales constructivos procedentes del yacimiento. Además encontró una serie de objetos que decidió conservar a la espera de que alguien revelara su significado (Martín Aguado, 1965, s.p. y Ramos y Durán, 1988, 237). En 1964 algunos de los objetos arqueológicos llegaron a manos de D. Máximo Martín Aguado. El interés que despertaron en el señor Martín Aguado, catedrático de Instituto de Toledo, le impulsó a realizar una primera visita al lugar de los hallazgos y llegó a la conclusión de que se trataba de una villa romana. A finales de ese mismo año se hizo cargo de las excavaciones, redactando el primer informe arqueológico. En sus trabajos puso al descubierto algunas habitaciones pavimentadas y más de un centenar de monedas recogidas en superficie. En uno de sus trabajos comenta el descubrimiento de "la casa señorial de la finca, dotada de calefacción, con paredes de piedra y revocadas interiormente de estuco, mosaicos de opus signinum y otros de opus tessellatum". Y con relación a los restos materiales señala "objetos de mármol blanco, objetos de granito, piezas de barro, útiles de metal, monedas y conchas de moluscos" (Martín Aguado, 1969).

En 1981 una serie de expoliaciones pusieron al descubierto una piscina bautismal de inmersión, un pavimento musivario y una estancia de planta rectangular con cuatro ábsides contrapuestos pavimentados con mosaicos. La acción de saqueo llegó a oídos de los responsables del Museo de Santa Cruz de Toledo quienes procedieron a la excavación del baptisterio y al levantamiento y traslado de los mosaicos (Ramos y Durán, 1988, 237). En 1982 se llevó a cabo la primera campaña de excavaciones realizada por el Departamento de Prehistoria y Arqueología de la UAM y dirigida por el Dr. Bendala. Para abrir las cuadrículas se tomó como referencia el camino de servidumbre. Por hallarse en trámite la expropiación de los terrenos arqueológicos, los trabajos científicos no se reanudaron hasta el año 1986, fecha en la que fue comprada la parcela de 5000 metros cuạdrados. En esta ocasión la campaña fue codirigida por el Dr. Bendala y $\mathrm{M}^{2} \mathrm{~L}$. Ramos Sainz. No se volvió a trabajar en este yacimiento hasta el año 1994, cuando el arqueólogo Domingo Portela llevó a cabo labores de limpieza y acondicionamiento del entorno.

Los trabajos arqueológicos llevados a cabo por la UAM se reanudaron en 1995. En esta ocasión se incorporó a la dirección de las excavaciones Dña. Raquel Castelo. Entre los meses de julio a octubre de 1996 tuvo lugar una nueva intervención del mismo equipo, que 


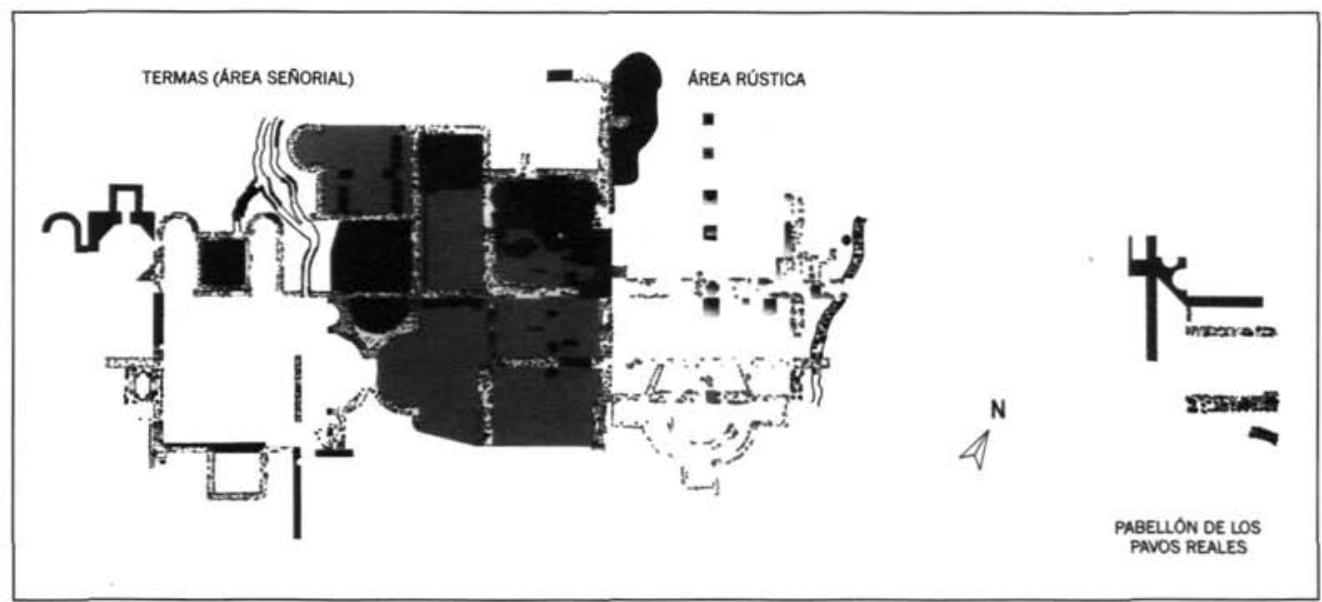

Figura 1. Plano de las excavaciones de El Saucedo (Talavera la Nueva, Toledo), (dibujo C. Sierra),

contó con trabajadores del INEM. Se contó con un restaurador (Fernando Hernández) y un arqueólogo (Domingo Portela), contratados por la Junta de Comunidades de Castilla-La Mancha. En 1999, incorporándose a la dirección de los trabajos D. Raúl Arribas Domínguez, se realizó una breve intervención así como un primer acercamiento desde el gabinete al medio natural del yacimiento (Mar Zamora, becaria del Departamento de Prehistoria y Arqueología de la UAM, fue la encargada de hacerlo) (fig. 2 y 3).

La última campaña, hasta el momento, tuvo lugar en los meses de septiembre a noviembre de 2000. Se contó con la colaboración del INEM y se contrataron dos arqueólogos: Ofelia Jiménez y Cristina Sierra. Los objetivos se articularon en tres ámbitos: Investigación: Se pretendía ampliar el conocimiento de las estructuras arquitectónicas en varios sectores; completar la planta de la villa con la conexión de áreas de funcionalidad distinta; estudiar el "Pabellón de los Pavos Reales"; estudiar asimismo, las técnicas constructivas de las nuevas estructuras aparecidas durante la excavación. También se planteó como objetivo prioritario completar el estudio sobre las diferentes actividades económicas y de representación social desarrolladas en la villa. Conservación: Se propuso consolidar las estructuras arquitectónicas y pinturas murales y cubrir el yacimiento una vez finalizada la campaña. Difusión: Se pretendió continuar con la difusión de los resultados de la investigación, tanto en el ámbito científico como hacia el público no especializado (Aguado et alii, e.p. a; Jiménez et alii, e.p.).

Actualmente, el yacimiento es, sólo en parte, propiedad de la Junta de Comunidades de Castilla-La Mancha, ya que su perímetro sobrepasa la parte adquirida. Las excavaciones han sido patrocinadas primero por la Dirección General de Bellas Artes del Ministerio de Cultura, después por la Junta de Comunidades de Castilla la Mancha y han contado siempre con la colaboración, la hospitalidad y buena disposición del Ayuntamiento de Talavera la Nueva. 


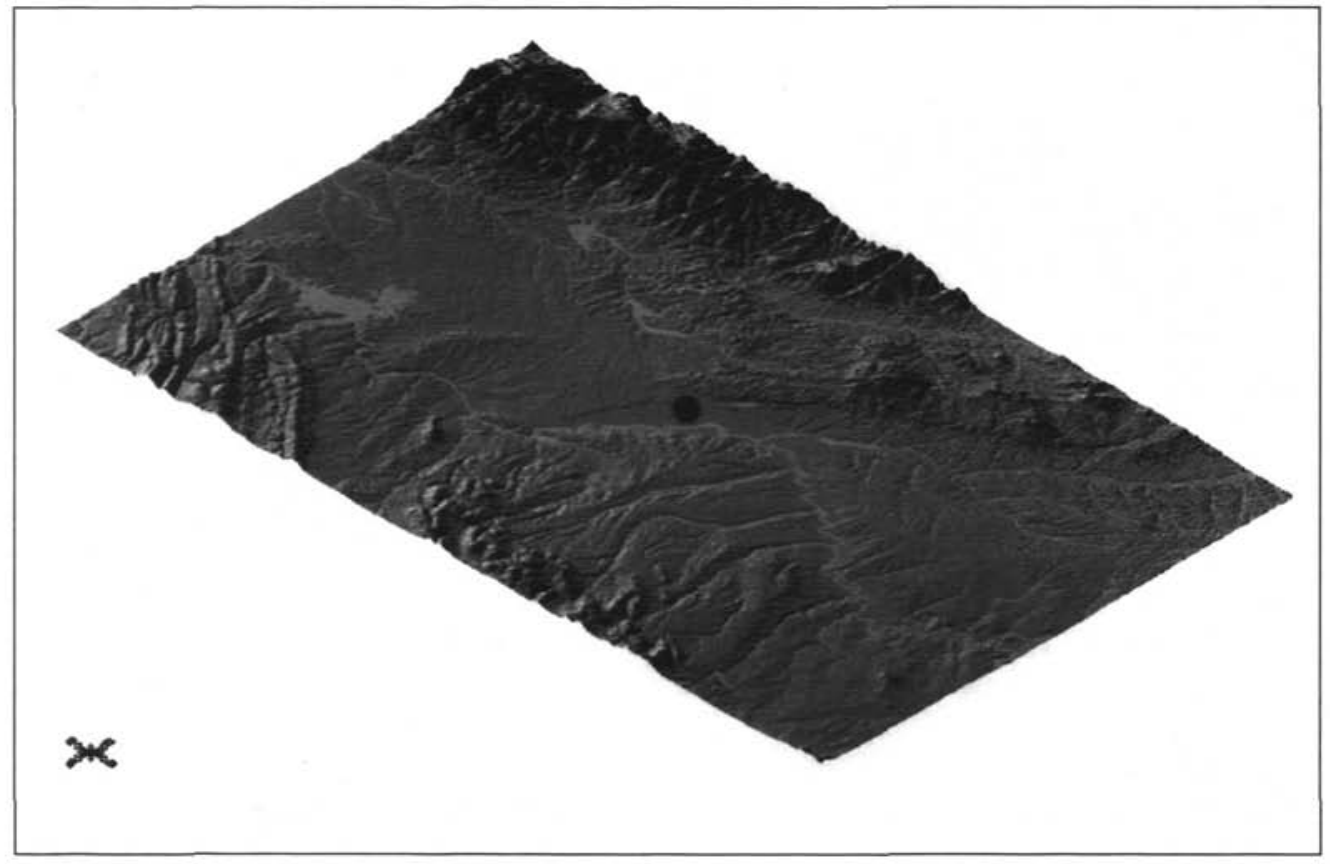

Figura 2. Situación de El Saucedo en relación a la orografía.

\section{ESTADO ACTUAL DE LA INVESTIGACIÓN}

\section{LÍNEAS DE INVESTIGACIÓN}

A continuación se presentan de forma esquemática las líneas maestras que se siguen actualmente en el desarrollo de la investigación sobre el yacimiento:

- Estudio de estructuras arquitectónicas: Conocimiento del espacio.

- Interpretación de las estructuras.

- Definición de espacios y sus funcionalidades.

- Análisis de sistemas constructivos y materiales de construcción.

- Análisis iconográficos.

- Reconstrucción de Actividades Económicas y modos de vida en general:

- Análisis de materiales (estudio del bronce, del vidrio, de los materiales relacionados con el tiempo de ocio, estudio cerámico, de la placa de cinturón, etc.) 


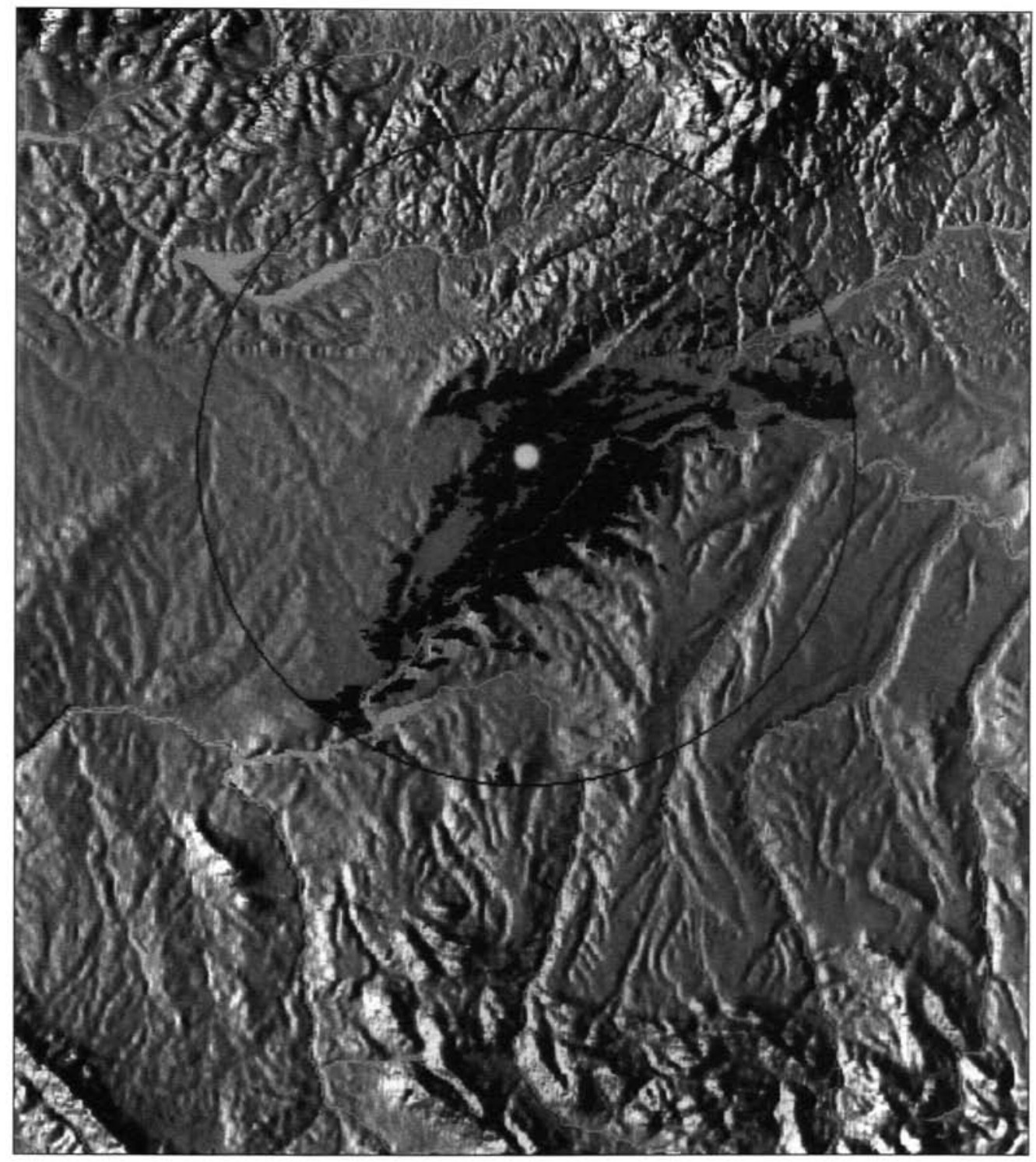

Figura 3. Reconstrucción de la visibilidad desde el yacimiento de El Saucedo. (Mapas elaborados por Mar Zamora) 


\section{- Reconstrucción del Paleoambiente. Línea de investigación que se desarrolla con vocación interdisciplinar.}

- Análisis arqueozoológicos.

- Análisis paleobotánico- antracológicos.

- Análisis antropológicos.

- Análisis de paleomagnetismo.

- Reconstrucción del Proceso Histórico.

\section{ESTUdio Arquitectónico}

\section{Evolución Cronológica. Fases constructivas}

El creciente progreso de los estudios parciales y la intensificación de los trabajos en los tres últimos años, permiten alcanzar conclusiones sobre las características y la historia del yacimiento. Pese a todo, somos conscientes de la provisionalidad de algunas propuestas, y estamos a la espera de proseguir las excavaciones y de ultimar los estudios en curso.

La zona excavada fue dividida en dos Áreas, $I$ y $I I$ (fig. 4), situadas a uno y otro lado del camino de servidumbre (áreas que hoy ya se encuentran unidas, como tendremos ocasión de comprobar). Cada una de ellas presentaba rasgos peculiares: la denominada Área I, de carácter más fabril, ha permitido detectar en mejores condiciones las diferentes fases del yacimiento, que se suceden desde el Alto-Imperio hasta seguramente el siglo IX d. C., mientras que en la denominada Área II, más monumental, contiene la parte más importante de la segunda fase constructiva de fines del s. III o comienzos del siglo IV d. C., remodelada después para la conversión de sus espacios principales en basílica cristiana hacia finales del siglo V-comienzos del VI d. C.

La primera fase puede fecharse a partir de la segunda mitad del siglo I d. C., para alcanzar, al menos, el último cuarto del siglo II. Se conoce mejor en el Área I, donde se han hallado los restos de una fuente o estanque, correspondiente a un patio o espacio abierto, aunque la planta en conjunto fue alterada. Por los datos cerámicos y por los indicios hasta ahora disponibles, puede corroborarse la cronología antes mencionada.

Tras un hiato o una época de muy escasa vitalidad, asistimos a una completa reestructuración. Es entonces, cuando este espacio se configura como una villa palaciega suburbana con amplias y complejas estancias termales y demás complementos. En sintonía con la construcción de las numerosas y grandes villas de época tardía, la gran reforma de la de El Saucedo debió ocurrir entre fines del s. III y comienzos del IV d. C.

La tercera fase constructiva es una importante reforma de la edificación existente, realizada hacia fines del siglo $\mathrm{V}$ comienzos del s. VI, particularmente bien documentada, 


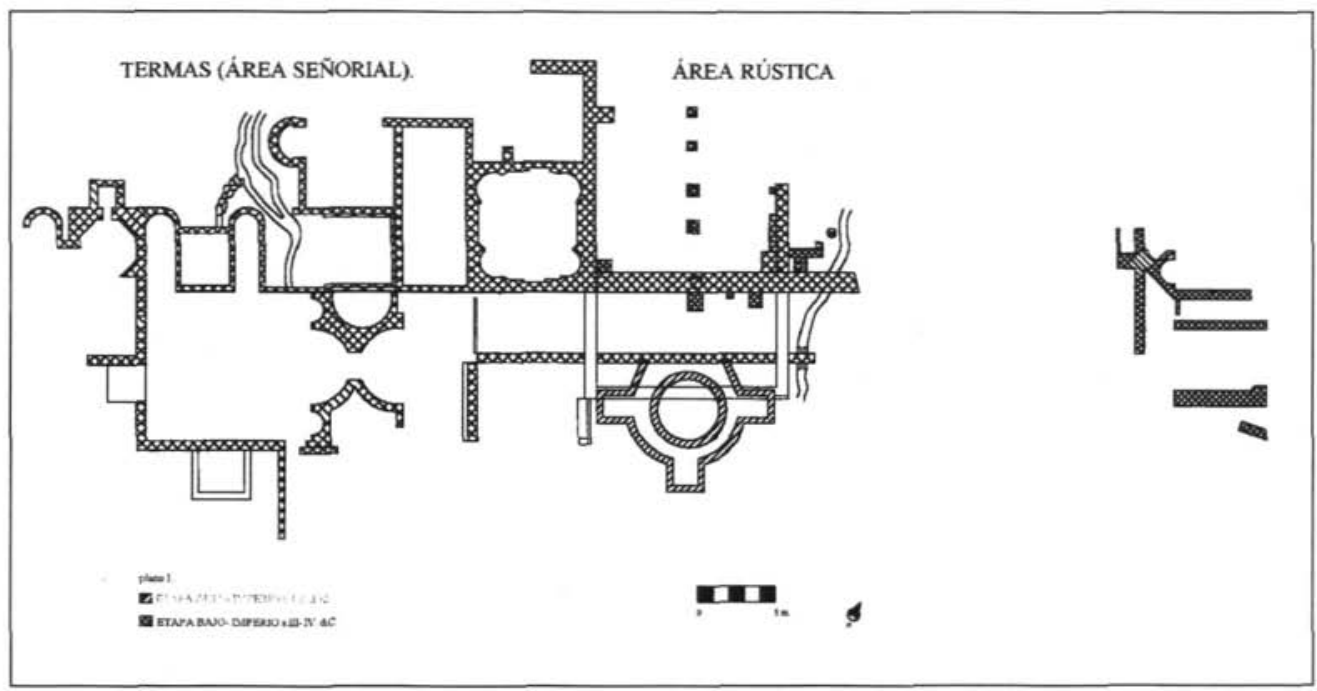

Figura 4. Planta de El Saucedo. Etapas Alto y Bajoimperial.

donde el gran salón de planta compleja fue remodelado para convertirlo en basílica de culto cristiano. En el Área I se observa la acción destructiva del fuego con la formación de un importante nivel de incendio. Había aquí una gran acumulación de tejas mezcladas con carbones y restos de vigas carbonizadas, producto del derrumbamiento del tejado, lo que contribuiría a ahogar el incendio y a carbonizar las vigas. Puede datarse el incendio por el hallazgo, bajo el nivel de carbones y tejas, de un triens de Witiza (702-710 d.C.) y de una placa de cinturón múltiple fechable a fines del siglo VII comienzos del VIII d.C.

Tras el incendio, manifestación principal de la destrucción del asentamiento al final de los tiempos visigodos y la transición a la Edad Media, presidida por el dominio musulmán de la península, el lugar muestra una última etapa constructiva, mal documentada pues quedan tan sólo algunas concentraciones de piedras situadas muy superficialmente, de las que no es fácil determinar las estructuras arquitectónicas a que correspondían. Sería ésta una última ocupación de carácter residual y restringida a determinadas zonas de la villa, la cual fue reaprovechada como cantera en un último capítulo de su propia historia.

A continuación presentamos de forma más pormenorizada las características de las dos fases de ocupación principales del yacimiento.

\section{A. ÉPOCA BAJO-IMPERIAL (Fines S. III - Comienzos del S. IV d.C.)}

Como ya hemos señalado, tras una primera fase de ocupación en un espacio temporal comprendido entre la segunda mitad del siglo I d.C. y fechas avanzadas e imprecisas del siglo II, y un hiato o época de escasa vitalidad, se crea una villa palaciega que no se 
aleja en las características generales de la arquitectura rural documentada en la Lusitania y distinguida por presentar una gran amplitud en las zonas señoriales, por la existencia de un conjunto termal en las inmediaciones o dentro de la zona señorial y de una rica decoración musivaria, pinturas murales y elementos decorativos de mármol. Igualmente, se sabe de la existencia de un basurero de este momento situado en las cercanías del gran salón absidado (en la parte posterior a la cabecera de la futura basílica).

Hasta la campaña del año 2000 se desconocía la relación entre los distintos ámbitos excavados. Gracias a los trabajos llevados a cabo en el transcurso de la misma se pudo constatar que las hasta entonces consideradas área señorial y área rústica formaron parte del mismo edificio o de la misma estructura arquitectónica, puesto que comparten un mismo muro. También se ha podido observar la existencia de lo que parece un atrio a cielo abierto en torno al cual girase un pasillo distribuidor, obteniéndose así una planta de atrio central o planta en U para la villa, en torno al cual, se ubicarían las distintas estancias. El pasillo distribuidor fue amortizado en épocas posteriores, construyéndose diversos muros que dieron lugar a nuevos espacios. (fig. 4)

\section{Área Señorial-Las termas}

En estudios precedentes, la descripción de las estructuras arquitectónicas de la pars urbana de la villa y el conocimiento de que disponíamos de la planta de la misma hicieron necesaria la diferenciación de tres áreas: una zona señorial, formada por un gran salón absidado, un edificio de funcionalidad termal y el denominado "Pabellón de los Pavos Reales". Esta diferenciación radicaba fundamentalmente en la enorme desproporción de dimensiones existentes entre el mencionado salón y el complejo termal, que obligaba a plantear una interpretación funcional distinta para cada uno de los ambientes.

En la actualidad, los resultados de las últimas intervenciones arqueológicas y la ampliación del área puesta al descubierto han permitido documentar la identificación de las dos primeras como una sola, esto es, la estancia poliabsidada interpretada como una sala de recepción o aparato, formaría parte del complejo balnear. Éste, a su vez, debió de ser uno de los conjuntos arquitectónicos que debieron de integrarse en una pars urbana o área señorial de mayores dimensiones, de la que actualmente sólo podemos conocer el edificio indicado. La descripción pormenorizada de estos espacios ha sido ya publicada anteriormente (Bendala et alii, 1998, 302-306). La planta completa se puede consultar en la figura $\mathrm{n}^{\circ} 5$.

Por lo que se refiere al salón absidado, su disposición, dimensiones y características constructivas y decorativas avalan la hipótesis de su interpretación funcional como un espacio de recepción y aparato, que además jugaría un papel como distribuidor, lugar de paso desde el que acceder a las distintas estancias del complejo termal, y por tanto, habría sido planificado para facilitar la organización del itinerario termal. Dentro de las villae lusitanas encontramos espacios con funcionalidades semejantes. En este sentido, podemos mencionar el ejemplo de la villa de La Dehesa de la Cocosa (Badajoz) (Serra Ráfols, 1952). 


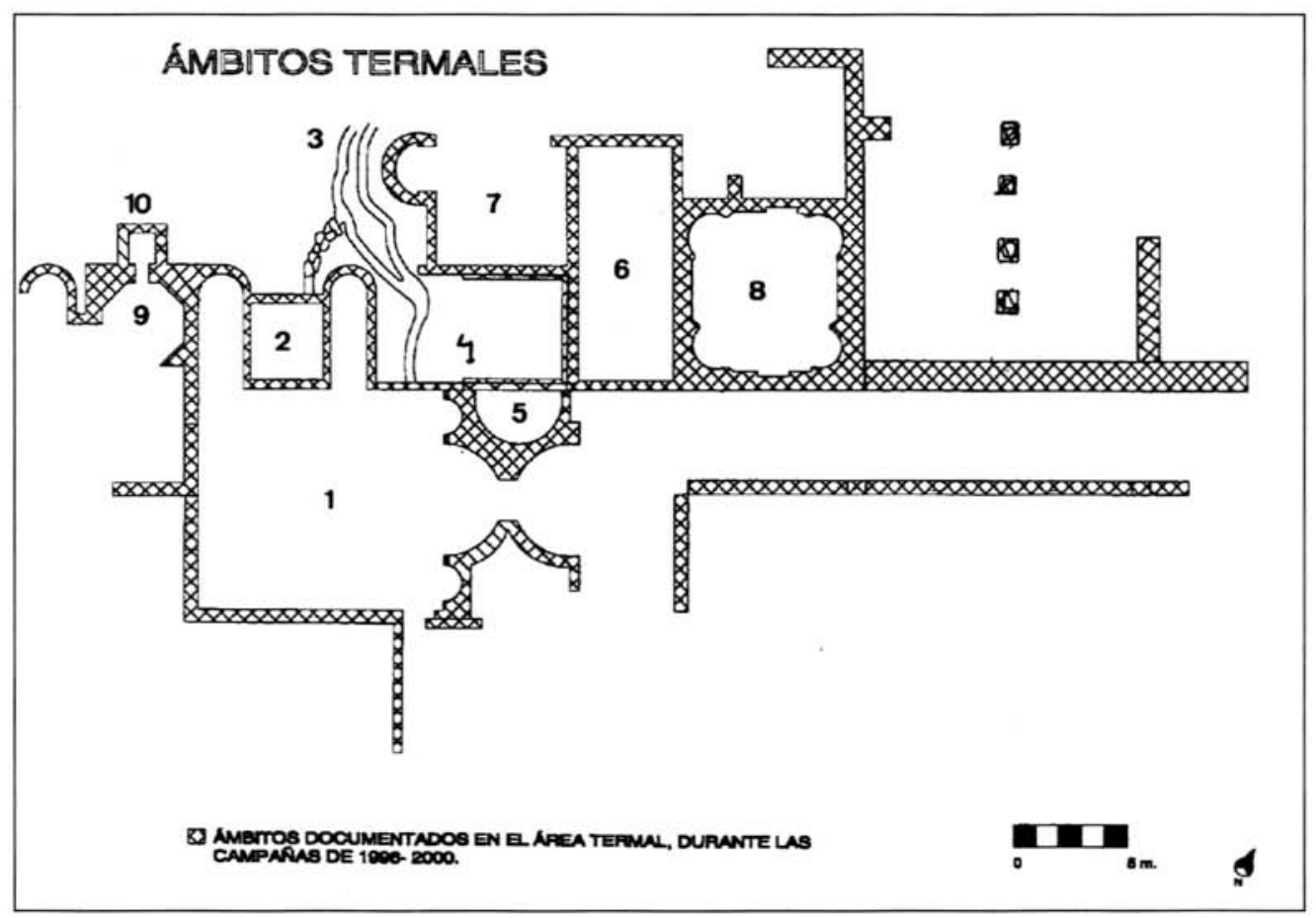

Figura 5. Planta del conjunto termal de El Saucedo.

Por último, respecto a la cubierta de la habitación absidada, es difícil recomponer la techumbre, aunque las dimensiones del espacio interior entre muros y el grosor de los mismos permiten pensar que presentara una vertiente a dos aguas, rematándose los ábsides laterales mediante pequeñas cúpulas de cuarto de esfera.

Por lo que se refiere al complejo balnear, la primera noticia que aparece publicada acerca de la existencia de un sistema de calefacción en la villa es aportada por el catedrático de Toledo M. Martín Aguado (1965). No será hasta muchos años después, cuando, con el inicio de las excavaciones científicas en 1982, comience a conocerse con detalle el sector termal de la villa. En el II Congreso de Arqueología Peninsular, celebrado en 1996 (Castelo et alii 1999, 271), aparecen publicados los primeros datos sobre las estancias termales excavadas hasta el momento. Poco después se llevó a cabo un estudio más minucioso de estas estancias calefactadas, de sus técnicas constructivas, de los sistemas de calefacción por bypocaustum y concameratio, así como de los paralelos hallados en función a todos estos aspectos mencionados (Castelo et alii, 1997). En 1997 se prestó especial atención a los sistemas de calefacción mencionados en sendos trabajos (Arribas 1999; Torrecilla, 1999). Al año siguiente se realizó un estudio arquitectónico y cronológico general del yacimiento, en el que se recogían los hallazgos e interpretaciones actualizados hasta entonces 
en el área termal (Bendala et alii, 1998, 304-306), que, a su vez fue objeto de un estudio monográfico durante el año 1999 (Arribas y Torrecilla, 2000).

En primer lugar, cabe destacar el gran salón absidado (fig. 5.1), al que se accede desde una zona posiblemente porticada, en torno a un atrio o área a cielo abierto, mediante unas fauces en forma de dos exedras semicirculares contrapuestas. Un paralelo de este tipo de entrada se observa en la villa Las Mezquitillas (Cortijo de Fuentidueñas, Écija, Sevilla) (García y Bellido, 1952). Las fauces de El Saucedo se encuentran flanqueadas interiormente por sendos nichos semicirculares, aunque de menor tamaño, que se hallan precedidos por dos columnas, adosadas a ambos lados, formando un paramento interior articulado. Esta sala fue lujosamente decorada mediante un pavimento musivo polícromo que representa motivos geométricos y figurados de gran belleza, en el que destaca una-plaqueta sumidero de mármol (fig. 10.1). Por esta causa se pensó inicialmente que habría cumplido la función de estancia de representación, quizás como oecus o tablinum, tal y como era usual en otras villae, como las de la Dehesa de la Cocosa (Serrá Ráfols, 1952), o Torre Águila (Rodríguez Martín, 1995) en las que se documentan espacios similares que anteceden a los complejos termales. Junto a esto, pensamos que este ambiente se configura además como un espacio distribuidor de las termas, es decir, un lugar de paso desde el que acceder a las distintas estancias del complejo y que por tanto habría jugado un papel importante en la organización del itinerario termal. Los muros de esta estancia presentan una cuidada factura, y debieron de hallarse decorados en el interior con ricas pinturas murales, y al exterior, en el zócalo también se han documentado pinturas de imitación de crustae (fig. 10.2). En su lado oeste, el salón se prolonga en forma de dos pasillos rematados por sendos ábsides semicirculares decorados con mosaicos, que habrían permitido el acceso a una pequeña piscina ( 3 '5 $\times 2$ '5 aproximadamente) de agua fría que se ubica entre ellos (figs. 5.2 y 9.1), hallada durante la última campaña de excavaciones. El acceso era posible mediante escalones en tres de sus flancos, incluso desde el gran salón, lado en el que se ha conservado el arranque de uno de estos escalones en opus signinum. Este material reviste toda la piscina. También se han conservado las canalizaciones de desagüe, que conectan con otros canales situados al este de la misma (fig. 5.3). Dichas conducciones, de aproximadamente $30 \mathrm{cms}$. de anchura, fueron excavadas en la arcilla natural, siendo enlucidas posteriormente y levantadas mediante dos pequeños muretes paralelos, construidos con fragmentos de ladrillos, ripios y guijarros. Se cubrían mediante grandes lajas de piedra.

El pasillo más oriental daría acceso, así mismo, a una sala rectangular con una superficie aproximada de unos $30 \mathrm{~m}^{2}$, con pavimento de opus signinum, rematado por cuarto de bocel, que recorre todo el perímetro de la estancia (fig. 5.4). A ella se abre un ábside semicircular en su lado sur, también solado con opus signinum (fig. 5.5). Sus características constructivas y el empleo en la misma de este tipo de pavimento hidráulico, avalan la interpretación funcional de esta estancia como una sala fría o frigidarium. Por su parte, todo su flanco occidental fue totalmente arrasado, dejando al descubierto la canalización subyacente, que surge bajo el mosaico del gran salón absidado.

La siguiente estancia, al este de la anterior, tiene forma rectangular, de $16 \mathrm{~m}^{2}$ aproximadamente, interpretándose como un espacio templado de transición entre ambientes fríos y cálidos o tepidarium (fig. 5.6). Se halla dividido, a su vez en dos ambientes dife- 
rentes, que se comunicarían por una puerta, de la que se reconoce en el suelo la huella de las jambas y una serie de agujeros dónde se imbricarían los postes o pies derechos que soportarían el peso de al cubierta en esta zona (Bendala et alii, 1998, 305; Arribas, 1999, 385-387).

En su lado oriental, existe otra habitación rectangular, con una superficie cercana a $\operatorname{los} 18 \mathrm{~m}^{2}$, que comparte parcialmente el muro norte del frigidarium y que está dotada también con un hypocaustum, sobre el que se situaría el pavimento de uso de la estancia, en opus signinum. Se trata del caldarium (fig. 5.7). Se remata la estancia en su flanco nororiental por una exedra semicircular que debió de cumplir la función de alveus o bañera de agua caliente. El hipocausto es del sistema de arquerías formadas por tres arcos cada una (Bendala et alii, 1998, 305; Arribas, 1999, 385-387). Este modelo de arquerías, que parece derivar del sistema de pilae, sería ciertamente común en las provincias occidentales, a excepción de la Península Itálica. Es empleado mayoritariamente en los complejos calefactados presentes en Lusitania, frente a las pilae de las termas tarraconenses (Bendala et alii, 1998, 305-306; Arribas, 1999, 391-392). Entre los hipocaustos más similares a los de El Saucedo podemos citar el excavado dentro del área urbana -C/ San Clemente y Ronda Surde Talavera de la Reina (Pacheco-Moraleda, 1997), el de la Casa-basílica de Mérida (Floriano, 1944; Durán 1991), o el de la villa de Monroy (Cerrillo et alii, 1988).

Al este del tepidarium se ha excavado durante la última campaña del año 2000 una habitación de planta peculiar, cuadrangular con un ábside semicircular en cada esquina, así como dos pequeñas exedras rectangulares, de $25 \mathrm{~cm}$. de profundidad en los muros norte y sur, respectivamente (fig. 5.8). De esta forma se constata que la hasta ahora considerada área rústica y la señorial formaban parte del mismo edificio, aunque se encuentran claramente diferenciadas por las características en planta de las habitaciones, sus acabados interiores, (decoración parietal estucada y varios suelos superpuestos de argamasa, el superior de opus signinum, en el caso de la habitación absidada), y los materiales hallados en las mismas.

En la villa de "Los Quintanares" (Rioseco, Soria), cuya vida se extiende entre la segunda mitad del siglo II y el siglo V, existe una habitación, J, muy similar en cuanto a tamaño y el tipo de planta, ubicada al sur de un peristilo. Se interpretó como un posible larario o santuario familiar, con mosaico geométrico, en cuyo centro se muestran dos cuadrados entrelazados, que generan un octógono en el centro, al igual que en Santervás del Burgo (Ortego, 1969, 237-238, lám. LXXX). Otra habitación de semejantes características la documentamos en la villa de "Los Villares" de Santervás del Burgo (Soria), la habitación presenta una planta circular inscrita en un cuadrado, está dotada de cuatro hornacinas con disposición en cruz (armaria lararia); es interpretada como una estancia de carácter cultual, debido a la propia planta, en la que las hornacinas habían albergado estatuillas de penates y lares. Ortego se basó para dar esta interpretación en otros hallazgos arqueológicos como la presencia de un mosaico con la figuración de la diosa Ceres y fragmentos de esculturas de mármol (Ortego, 1961, 221-223,226, fig. 2). Junto a la citada estancia se ubica otra de planta en forma de cruz con los brazos norte y sur rematados en ábsides, es muy similar a la documentada en la villa de Centcelles (Tarragona), (Hauschild y Arbeiter, 1993, 36-41). Fuera de la Península Ibérica se han hallado asimismo estancias termales con esta misma planta. En las termas flavio-trajaneas de Conimbriga (Coimbra, Portugal) pre- 
sentan una sudatio circular con cuatro ábsides (Correia y Reis, 2000, 274-276, fig. 3). Así, por ejemplo, en La Brunette (Orange), termas fechadas a fines del s. I a.C., en las que se constata un laconicum circular con cuatro ábsides (Bouet, 2000, 38, fig. 6a). La misma función tenía la estancia circular con tres ábsides de las termas altoimperiales de Lauro di Nola (Italia) (García Entero y Arribas, 2000, 88, fig. 1). En Gallia Belgica las fases I (segunda mitad del s.I d.C.) y II (segunda mitad del s. III) de las termas de Echternach presentan una estancia circular con cuatro ábsides, interpretada como laconicum en la fase I y como sudatio en la fase II (García Entero y Arribas, 2000, 90, fig. 2).

Al norte de esta estancia se ha constatado también recientemente la existencia de un espacio, que parece no haber sido cubierto, dada la factura de los muros y la localización de un pequeño basurero, del que se recuperó un esqueleto casi completo de un neonato (en fase de estudio), y un hogar similares a los aparecidos en otras zonas también exteriores de la villa.

Por último, en el lado oeste de los pasillos absidados que rodean la piscina de agua fría se han excavado en la última campaña una serie de estancias calefactadas, cuya funcionalidad queda reducida todavía a una mera hipótesis de trabajo, que se irá concretando a medida que avance el estudio de materiales, de las técnicas constructivas y de sus peculiares plantas, y que vaya ampliándose la zona de excavación. En primer lugar, adyacente al pasillo oeste, se ha descubierto una habitación de planta octogonal, (sin terminar de excavar, pues se encuentra atravesada por la acequia para el riego) (figs. 5.9 y 9.2). A ella se accedería a través de una habitación de planta todavía desconocida, situada en su lado sur y conectada con el gran salón absidado. El muro del lado noroeste se abre a una exedra cuadrada que pudo haber albergado el praefurnium y el propnigeum que proporcionara el aire calefactado al conjunto, aunque sus reducidas dimensiones y el cierre existente en su flanco norte permiten pensar también en la presencia de una bañera calefactada en este lugar (fig. 5.10). A su vez, por su lado meridional, la estancia de planta octogonal da acceso a otra habitación dispuesta sobre hipocausto, de la que sólo se conoce su sector norte, en forma de exedra semicircular y con la que se comunica, a nivel del subsuelo, mediante un arco de ladrillo. En todos estos espacios se documentan las arquerías de sustentación de una suspensura de opus signinum y mosaico, totalmente fragmentada y derrumbada sobre el area. La disposición de su planta y sus características constructivas nos remiten a paralelos cercanos documentados en el Conventus Emeritensis, como el existente en la villa de El Hinojal de la Dehesa de las Tiendas, donde existe un laconicum o sudatio (habtación $n^{\circ}$ 15) de características similares, fechado en el siglo IV d.C. (Álvarez Martínez, 1976). A éste podemos añadir una serie de ejemplos más: un alveus de la villa de "La Dehesa de la Cocosa" (Badajoz), inscrito en una estructura octogonal (Serra Rafols, 1952); en la habitación número 11 de la villa "La Sevillana" (Badajoz), una estancia octogonal decorada con un mosaico del siglo IV e inscrita en un cuadrado de 3'5 x 3'20, cuya función no se especifica, aunque diferente a la de El Hinojal, y por tanto, no termal (Aguilar, 1991, 448, fig. 2); o en la "Villa de Pesquero" (Pueblonuevo del Guadiana, Badajoz), en la que se conserva un emblema central de forma octogonal de un mosaico, que estaría ubicado en una habitación también octogonal, relacionada con la zona noble de la vivienda (Rubio, 1989, 77, fig.3, lám. 5.2, 5.3 y 5.4). Igualmente existen paralelos en otras provincias hispanas, como en la Tarraconensis, de los que conocemos los ejemplos de la sudatio de 
las termas del SO de la villa de "Els Munts" (Altafulla, Tarragona), en sus fases I y II, datadas a partir de la segunda mitad del siglo III (Berges, 1973); en el "Soto del Ramalete" (Castrejón, Navarra), decorada con el mosaico de Dulcitius (Taracena y Vázquez, 1956); en Arroniz (Navarra), de la que se conserva solo un mosaico octogonal (Taracena y Vázquez, 1946, 424-425); en el área termal de la villa de "Veranes" (Gijón, Asturias), datada en la primera mitad del siglo IV (Fernández Ochoa et alii, 1997, 274, lám. I y fig. 2); en las termas "Los Arcos II" de Clunia (Burgos), de fines del siglo I inicios del s. II, con casi 12 metros de luz, adosada al exterior del muro E, y por tanto, a las estructuras del siglo III; en el sector II de la villa de "Los Torrejones" (Yecla, Murcia) decorada con un mosaico, (Amante et alii, 1991, 264,266,276,280; Ruiz Molina, 1998, 570). Fuera del ámbito peninsular se emplea también este tipo de planta en los espacios termales, como en las llamadas termas del' Indirizzo (Catania, Sicilia) del siglo III ó IV d.C., cuya estancia octogonal se interpreta como un caldarium; en los tepidarios de las termas de Mare en Leptis Magna (Libia) (Miguel, 1999, 136-137) o en las termas del Foro de Ostia, cuya habitación octogonal se interpreta como un beliocaminus, datado en 150 d.C. La sudatio de las termas de Carignan (Ardennes, Bélgica), datadas en la segunda mitad del s. I d.C., tiene planta octogonal con cuatro ábsides en cruz (García Entero y Arribas, 2000, 90, fig. 1). Ma Cruz Fernández $(1982$, 209) reafirma el carácter termal de las estancias con este tipo de planta en villas de aspecto señorial. La práctica totalidad de estas estancias termales de fechan en el siglo IV d.C.; reafirma el carácter termal de las estancias con este tipo de planta en villas de aspecto señorial. La práctica totalidad de estas estancias termales fechadas en el siglo IV d.C.; interpretación que parece en principio oportuna para el espacio documentado en $E l$ Saucedo.

En otro orden de cosas, hemos de destacar la aparición de ciertos materiales relacionados con la calefacción de las termas, cuyo número se ha visto enormemente ampliado durante la última campaña de excavación (Castelo et alii, 1997, passim, figs. 8-14; Torrecilla, 1999), por lo que evitaremos extendernos en los detalles. Aunque resulta interesante mencionar que durante la excavación del caldarium se documentaron una serie de clavos metálicos y tubos espaciadores o clavi coctiles, que, sin duda debieron de formar parte del sistema de concameratio o "dobles paredes" con el que iban dotados los muros de esta habitación.

En relación a la cubierta de estas habitaciones, fueron hallados en el bypocaustum de las termas dos fragmentos de ladrillos-dovela (tipo 4a) para construir bóvedas, a los que se añaden los numerosos ejemplares encontrados recientemente en la habitación octogonal y el ábside semicircular adyacente. De estos ladrillos se han constatado abundantes ejemplos a lo largo del s. IV, sobre todo en la Galia, Hispania y el norte de África (Fincker, 1986; Torrecilla, 1999).

Por lo que se refiere a la fecha de construcción del complejo termal, ésta corresponde a la segunda fase, entre fines del s. III y comienzos del s. IV d.C. En su tercera fase (fines s. V ó inicios del s. VI), las termas se hallaban ya fuera de su uso original, y posiblemente destruidas en parte, pues algunos ladrillos-dovela y de arquerías aparecen reutilizados en la pila bautismal. Este hecho documenta el abandono del edificio o la pérdida de la funcionalidad termal para la que había sido proyectado el complejo (Bendala et alii 1998, 305). (Fig. 6.1; 6.2; 7.1; 7.2; 8.1; y 8.2). 

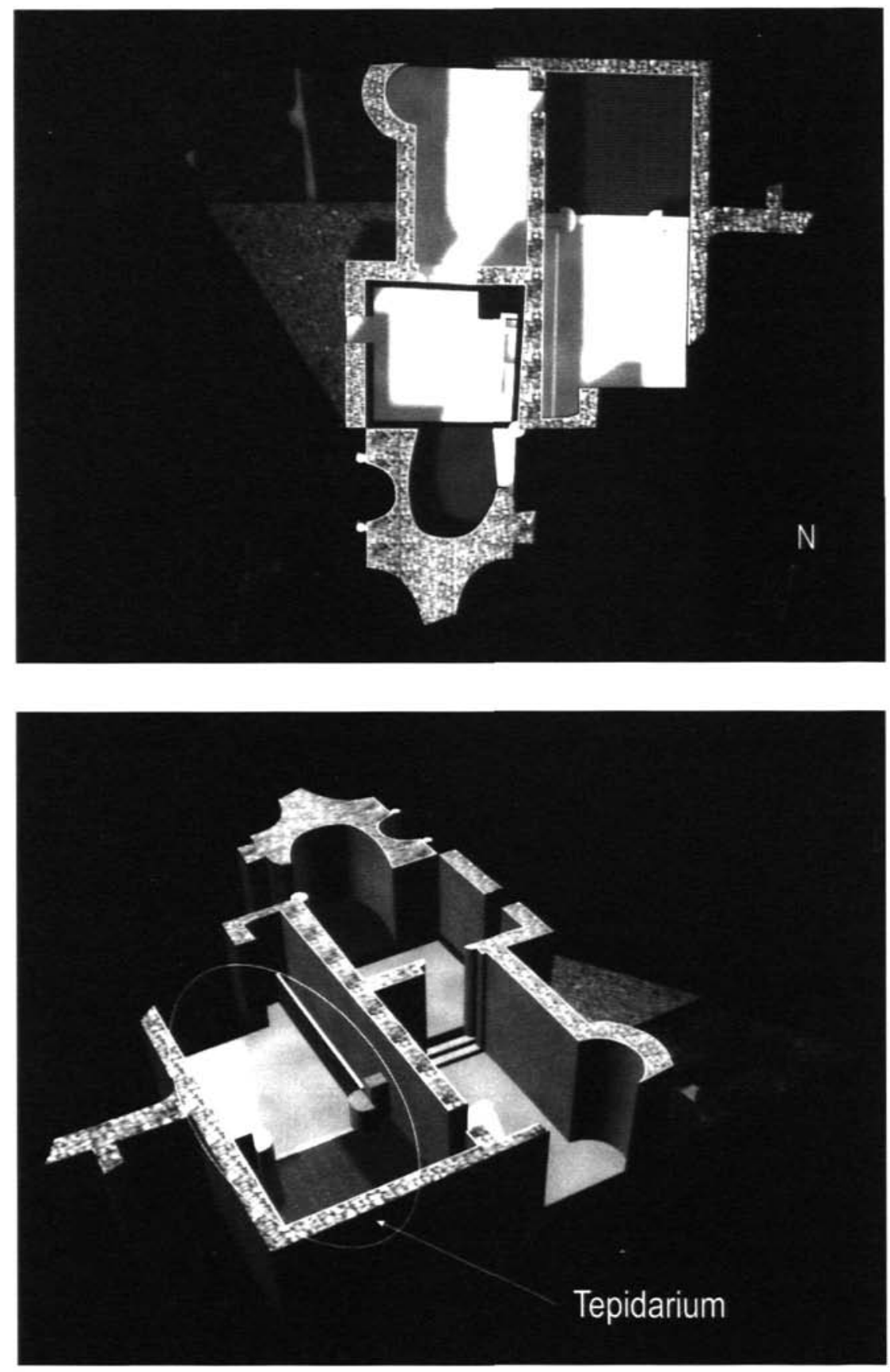

Figura 6.1. Vista en planta del conjunto termal. 6.2. Vista del tepidarium y concameratium. 


\section{Area señorial. Pabellón de los Pavos Reales}

Nos queda por último mencionar el Pabellón cuadrilobulado (fig. 10.3). Fue sacado a la luz antes de nuestras intervenciones arqueológicas de 1982 por miembros del Museo de Santa Cruz de Toledo, que también se encargaron del levantamiento y traslado de los pavimentos musivarios, al citado centro. Está formado por una planta cuadrangular que presenta en cada uno de sus lados una sala rectangular rematada por dos ábsides contrapuestos. De éstas cuatro salas sólo se conservan dos. Hasta la campaña del año 2000 este pabellón se encontraba inconexo con el resto de la villa pero al procederse a su reexcavación se ha situado en planta respecto al resto de los edificios (fig. 4), se ha obtenido su estratigrafía y se ha determinado que posee la misma orientación que el resto de las estancias del complejo termal, así como la misma cronología. Se trata también de la zona donde aparecen los materiales de mayor calidad y riqueza, por lo que podríamos pensar que se trata del área de la domus señorial. Por otro lado, la ubicación dentro de las villas de las habitaciones destinadas a la vivienda en áreas algo alejadas y separadas de los espacios termales, a fin de evitar las molestias ocasionadas por los humos y por el riesgo de incendio, nos aporta otro argumento para avalar dicha interpretación.

\section{Los pavimentos musivarios del área termal y del pabellón de cuatro ábsides.}

Los mosaicos de El Saucedo están realizados con teselas de diversos colores, siguiendo la tónica general de los mosaicos bajoimperiales, ya que será a partir de los ss. III y IV cuando se inicie el desarrollo de la policromía. Los mosaicos son en su mayor parte geométricos, aunque aparecen algunos motivos figurados. No se alejan de los pavimentos documentados en otros latifundios del valle del Tajo, Duero o Ebro que se cubren con extensas alfombras musivas. Por toda esta zona se observan talleres formados en los mismos círculos artísticos, que se caracterizan por su exuberante policromía y un gusto por las composiciones geométricas, fáciles de realizar, que no requieren la presencia de grandes maestros y en las que prevalecen octógonos, cuadrados y otras figuras geométricas que se multiplican hasta recubrir la totalidad del pavimento. En todo este ámbito Mérida jugó un gran papel como impulsor y difusor de estos talleres. Aunque no resulta nada fácil distinguir talleres concretos, se observan mosaicos que, si no pertenecen a los mismos talleres, sí, al menos, a los mismos círculos artísticos (Torrecilla et alii, 1999).

Los mosaicos $n^{\circ} 1,2,3,4$ y 5 se sitúan en el gran salón absidado, mientras que los mosaicos $n^{\circ} 6$ y 7 pertenecen al Pabellón de los Pavos Reales. Parte de ellos se conservan in situ, otros en el Museo de Santa Cruz de Toledo y el resto en Talavera la Nueva (Toledo). Las descripciones pormenorizadas de los mosaicos han sido publicadas con anterioridad (Torrecilla et alii, 1999, 436-447).

- Mosaico $\mathrm{n}^{\circ} 1$ (figs. 11.1): octógonos irregulares, cruces latinas adyacentes que forman bexágonos oblongos. Se ha constatado en los talleres de las provincias occidentales, fechados entre los ss. IV y V, así como en las provincias orientales: Grecia y Hungría. Hemos de hacer constar que, en este caso, no se han encontrado paralelos en el norte de 

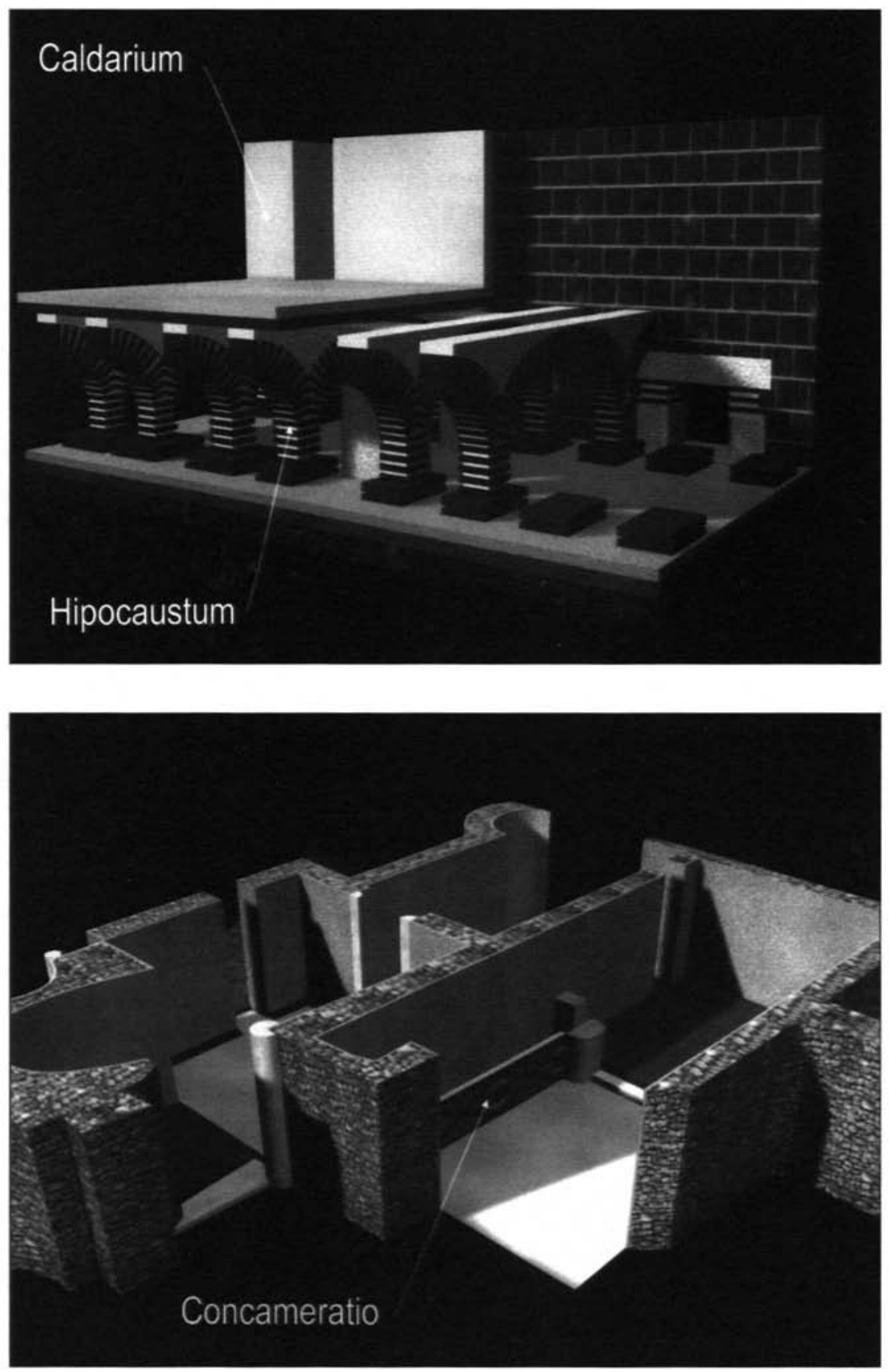

Figura 7.1. Vista del Caldarium e bipocaustum. 7.2. Vista del Concameratium. 

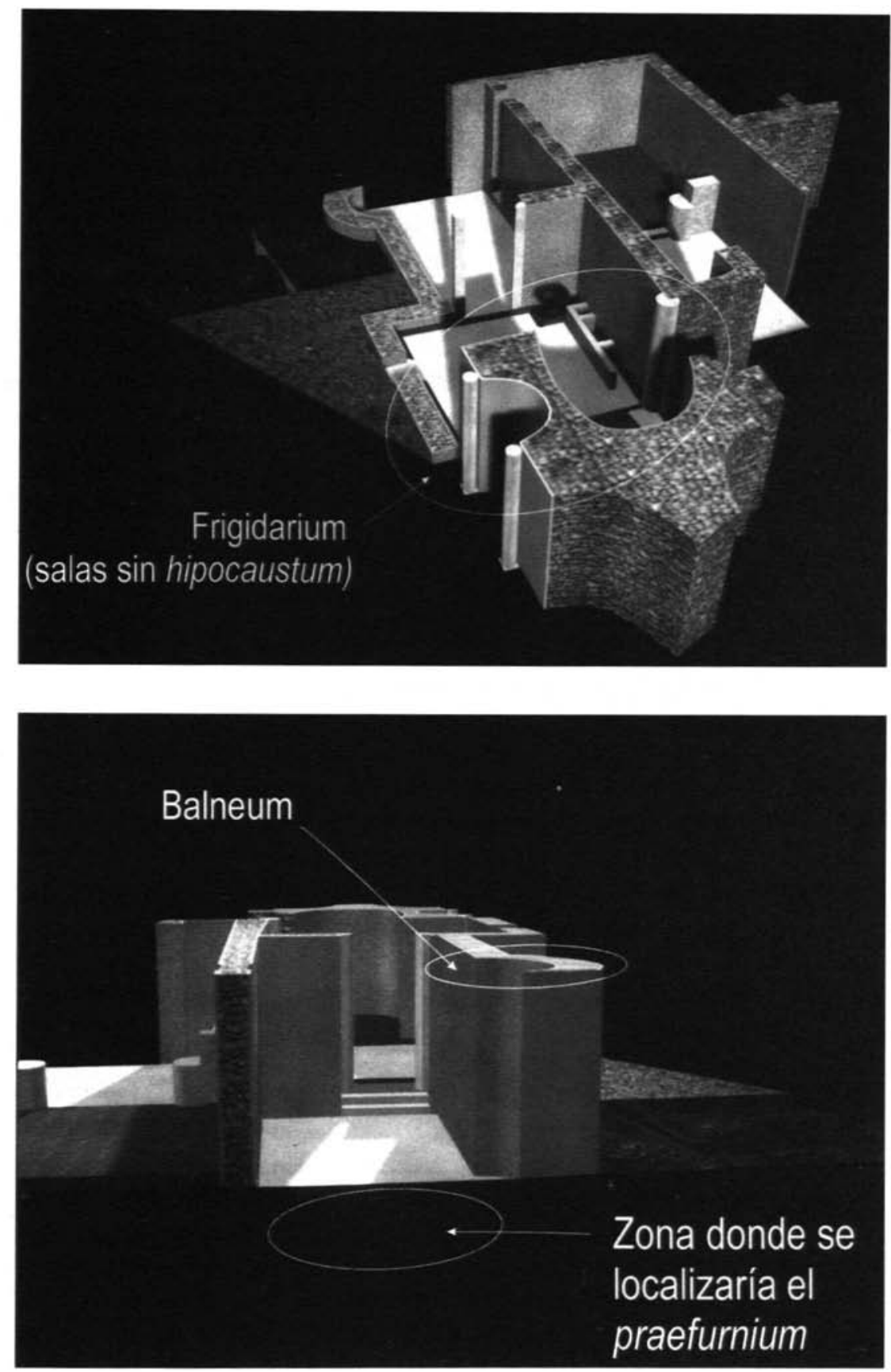

Figura 8.1. Estructura absidal y posible frigidarium. 8.2. Posible alveus del caldarium. 
África. En la península ibérica lo hemos hallado en las dos Mesetas, en Andalucía, en el sudeste y Portugal.

- Mosaico $\mathrm{n}^{\circ} 2$. Composición ortogonal de círculos secantes que dejan entrever cuadripétalas. Los pavimentos más antiguos se han documentado en Germania y en el Norte de África (ss. I-II) y se ha constatado su perduración hasta el s.V en Galia y Hungría. En la Península Ibérica, las cronologías más antiguas proceden de Tarragona, Sevilla y Barcelona en monumentos de fines del s. I-II, mientras el resto de los pavimentos tienen cronologías que oscilan entre los ss. II-IV. Es interesante mencionar un mosaico hallado en San Pedro de Tarrasa, con una cronología del siglo IX que demuestra la perduración de éste motivo en la musivaria hispana. En cuanto a los delfines con las colas entrelazadas y enroscadas a un tridente que se encuentran representados en el ábside (fig. 10.3), no los hay en cartones de talleres occidentales ni orientales. No obstante, en los primeros sí se observan algunas figuraciones semejantes, en las que los delfines aparecen con las colas entrelazadas y enroscadas a un ancla (en Galia, Suiza y Germania con cronologías de Época Altoimperial o Bajoimperial, momento en el que se fechan la mayor parte de los ejemplares). En el caso de la Península Ibérica, sólo se han documentado en Cataluña y Portugal con cronologías que abarcan los ss. II y III d.C.

- Mosaico $\mathrm{n}^{\circ}$ 3. Composición ortogonal de octógonos y cuadrados. Encontramos sus primeras representaciones en Italia. Se ha constatado en la Galia (desde el s.I hasta los ss. III-IV), así como en el Norte de África (entre los ss. III-IV), en las provincias orientales, y en Israel (s. VI). En el caso de Hispania, este esquema se generalizó a partir del siglo IV, coincidiendo con el florecimiento de la musivaria en los establecimientos rurales. No obstante, observamos ejemplos fechados con anterioridad: en el siglo II (Mérida y Sevilla) y en el s. III (Sevilla, Barcelona y Portugal), y otros fechados con posterioridad en el siglo V (Guadalajara). Los talleres Emeritenses, cuya actividad se desarrolló entre los ss. II-IV, parecen haber experimentado un interés especial por este tipo de temas compuestos de octógonos secantes y tangentes.

- Mosaico $\mathrm{n}^{\circ}$ 4. Corresponde al mosaico de ISCALLIS, situado en la cabecera de la basílica tardía, de modo que se describe más adelante.

- Mosaico $n^{\circ} 5$ (fig. 10.3). Estrella de ocho puntas obtenida a través de la unión de dos cuadrados en lacería de trenzas acantonada con rombos. Corresponde, en líneas generales, a motivos y esquemas que tienen una tradición surgida en el siglo I d.C., pero se generaliza en Época Bajoimperial. El motivo puede aparecer aislado o formando composiciones y se ha documentado en talleres occidentales y en el Norte de África (los ejemplos más antiguos, fines del s. II). Al menos, que nosotros conozcamos, no existen representaciones semejantes en los talleres orientales. El mayor número de ejemplos se alcanza en el siglo IV en África, Galia y Gran Bretaña. En el caso de Hispania, es frecuente encontrar el motivo en toda la península. Se ha figurado en pavimentos fechados a mediados del siglo II y III (Itálica) pero sobre todo en aquellos datados en el siglo IV.

- Mosaico $n^{\circ} 6$ (fig. 10.3). Círculos, cuadrados y rectángulos curvilíneos o carretes. De nuevo nos encontramos con un motivo ausente de los talleres musivarios orientales. En los talleres occidentales el motivo se representó con mayor asiduidad. Aunque se conoce 
en pavimentos fechados desde fines del siglo II hasta el siglo V, el mayor número de ejemplos están datados a fines del siglo II y comienzos del s. III. En el caso de la Península Ibérica llama la atención su ausencia en Andalucía y Sudeste peninsular. Las cronologías más antiguas se han constatado en Navarra (ss. I-II), y las más modernas en Soria, Toledo, Ciudad Real, Badajoz y Portugal (s. IV). Es posible que las composiciones documentadas en la Meseta hallan salido de los talleres emeritenses o, al menos, que se produjera un intercambio de cartones o un desplazamiento de artesanos, que explicaría la gran variedad de diseños y motivos aún en las mismas. En cuanto a la figuración de los pavos reales, ésta no es extraña a los pavimentos musivarios debido a su natural belleza y a su vistosidad. Su representación es muy frecuente en el Norte de África, con cronologías que oscilan entre el siglo II y comienzos del s.IV. Su imagen fue adoptada por el cristianismo y así lo vemos documentado en edificios paleocristianos de Rávena. En referencia a la Península Ibérica solo podemos mencionar los ejemplos documentados en Murcia e Islas Baleares.

- Mosaico $\mathrm{n}^{\circ} 7$ (fig. 10.3). Hexágonos escutiformes cruzados dejando entrever octógonos, cuadrados y rombos. Ha sido documentado en Italia con cronologías de los ss. IIIIV; en el Norte de África (s. III) y en Israel (fines del siglo IV-comienzos del siglo V). En la Península Ibérica hemos encontrado un único caso en la villa de La Olmeda (Palencia). La composición de peltas (uno de los elementos decorativos más antiguos del repertorio temático de los mosaicos ornamentales romanos) que complementa este mosaico es frecuente en pavimentos de las provincias occidentales. Los ejemplos que pueden citarse para la Península son muy numerosos y abarcan regiones geográficas muy alejadas, con una amplia cronología, aunque la mayor parte de los ejemplos se fechan entre los ss. III-IV d.C. Su notable simplicidad permitió que fuera utilizada como elemento decorativo aislado o formando composición. Aparecen en el siglo I d.C. en Pompeya y su utilización fue masiva en Italia desde el siglo II d.C. y a partir de finales de esa centuria se empleó especialmente en orlas perdurando hasta el final de la Baja romanidad, sobre todo en pavimentos de Germania, Britania e Hispania.

Por último podemos determinar que en el caso de los mosaicos documentados en $\mathrm{El}$ Saucedo, se emplearon composiciones repartidas prácticamente por todas partes del Imperio. Se confirma una vez más que la musivaria hispana tardía no precisa explicarse mediante las creaciones norteafricanas, ya que todos los mosaicos participan de las modas difundidas en todas las provincias del Imperio, en todas sus épocas, además de participar en las propias tradiciones locales. No todos los mosaicos poseen de las mismas influencias.

\section{B. OCUPACIÓN DE LOS SS. V-VIII}

\section{Basílica cristiana}

A finales del siglo $\mathrm{V}$ comienzos del VI se produce una importante reforma de las edificaciones existentes: el gran salón de planta compleja (que formó parte del área termal) fue remodelado para convertirlo en basílica de culto cristiano (fig. 12). La basílica siguió 

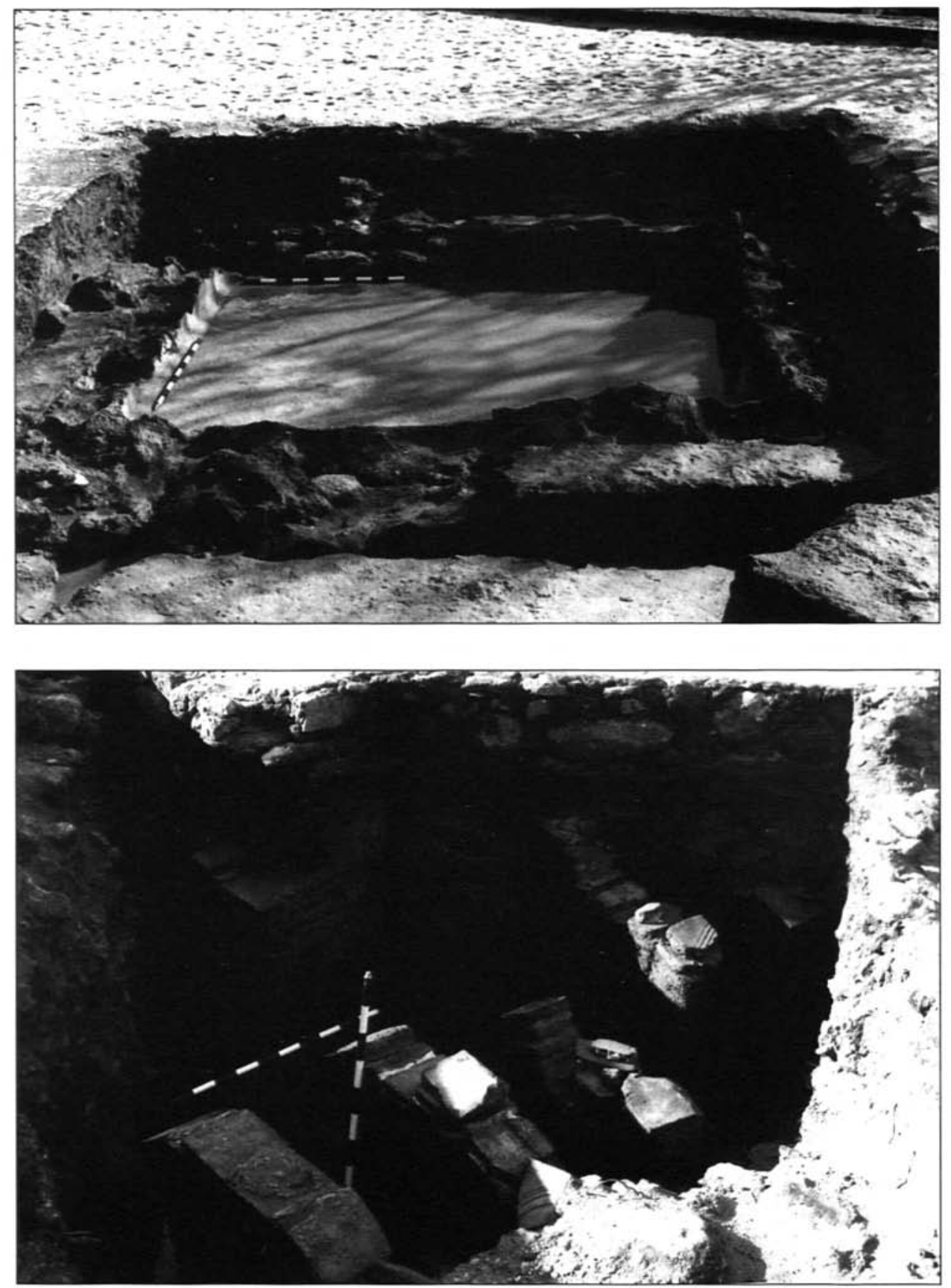

Figura 9.1. Piscina de agua fría del complejo termal. Figura 9.2. Habitación octogonal con hipocausto. 

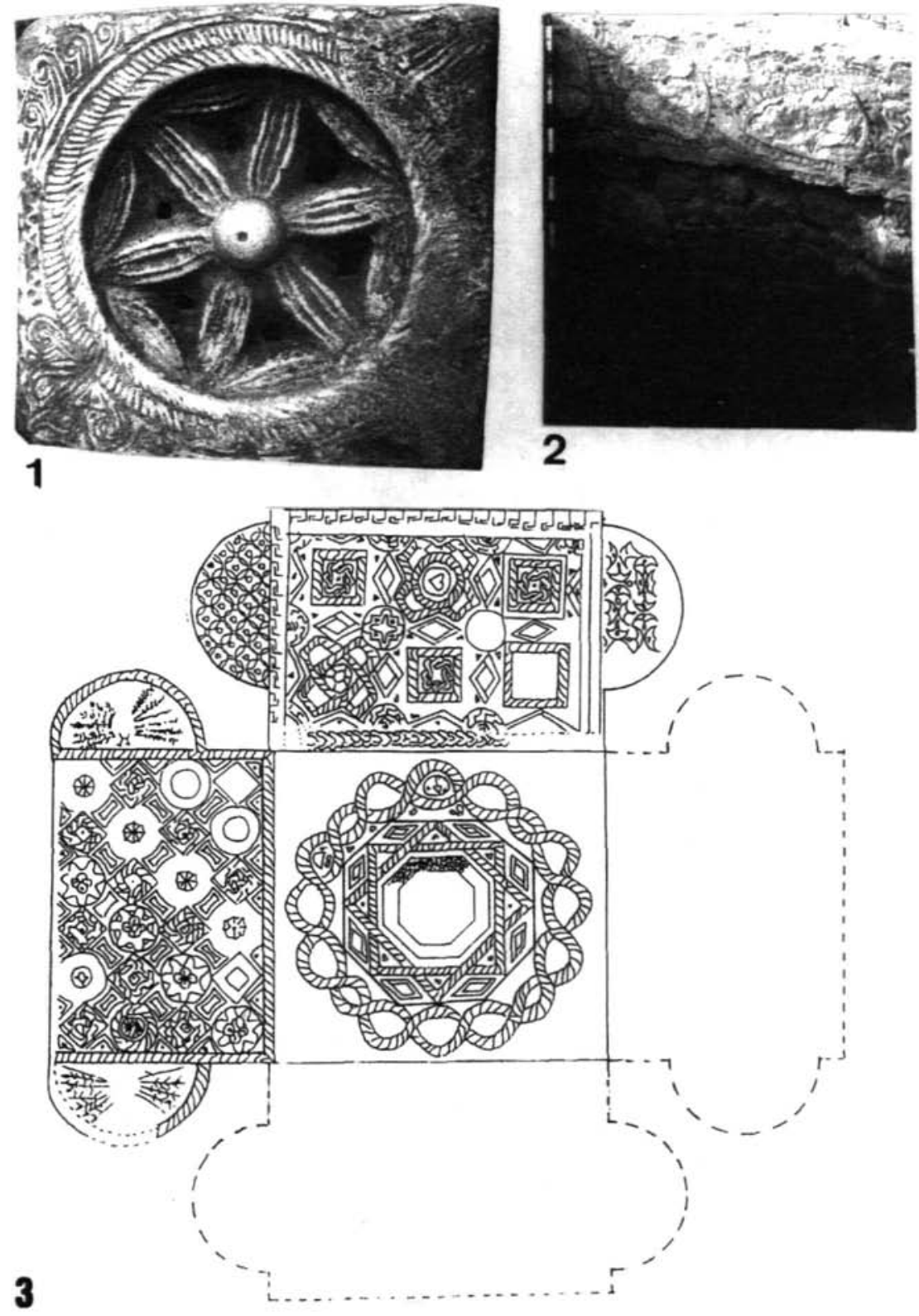

Figura 10: 1. Sumidero del mosaico $n^{\circ} 1$. 2. Detalle de la decoración del muro exterior, al este de la cabecera cuadrangular. 3. Composición de los mosaicos del "Pabellón de los Pavos Reales". 
perteneciendo a la Lusitania, al Conventus jurídico Emeritensis y debió de tener como sede Episcopal Salmantica. Es posible que la edificación de la basílica estuviera relacionada con la intención de cristianizar un lugar ya sagrado en época prerromana y romana, lugar donde debió desarrollarse un culto a las ninfas.

Se ha comprobado que la reforma se hizo sobre la base de una construcción prácticamente desmontada que podría estar más o menos arruinada o fue derruida intencionadamente para proceder a la gran reforma programada. El hecho es que los muros quedaron eliminados hasta unos $50 \mathrm{~cm}$. de altura.

Los cambios se pueden sintetizar en los siguientes:

1. Apertura de un hueco en el muro suroriental para adosar una cabecera (fig. 13.1). Se comprueba un cambio en la técnica de construcción aunque se procura un notable mimetismo en casi todo, desde el tipo de mampostería a la decoración externa del zócalo. La cabecera cuadrangular presentaría una cronología anterior a la propuesta por el Dr. Cerrillo Martín de Cáceres, quien considera que las cabeceras cuadrangulares harían su aparición a partir del año 600, tal como se puede constatar en La Cocosa; Las Corias, Los Santiago, Valdecebadar; Burguillos del Cerro; Magasquilla de los Donaire de Ibabernando, etc. A partir del 650 comenzaría una progresiva popularización de esta tipología. Se cree que serían los alrededores de Mérida la zona geográfica que constituyó el centro de estos cambios y que éstas cabeceras cuadrangulares serían de influencia oriental, procedentes de las costas sirias hasta el Adriático. Esta influencia del mediterráneo oriental que se detecta en la forma de la cabecera coincidiría con la que presenta el pavimento que se colocó en ella. Por otro lado, la cabecera de El Saucedo debería integrarse en el segundo grupo establecido por el Dr. Cerrillo, caracterizado por presentar un santuario que se abre en su totalidad a la nave (Castelo et alii, 2000, 94).

2. Posible ejecución de la cruz latina que es diferente a las demás representadas en el tapiz central del salón absidado (fig. 14.2). Llama la atención que quedara centrada con respecto a la cabecera. Podría resultar extraño la figuración de la cruz, pero conocemos ejemplos en Israel, y además, en el año 427, Teodosio II y Valentiniano II promulgaron un decreto prohibiendo el Signum Christi en los suelos, lo cual implicaba que la cruz o el monograma y tal vez la propia efigie de Cristo, habían aparecido así representados con anterioridad en las diversas provincias.

3. Cambio en la organización del ambiente con la construcción de un muro que compartimentó la gran sala y dejó centrado el ábside de la cabecera. Fue levantado directamente sobre el mosaico, sin zanja de cimentación. Se pudo comprobar que el pavimento musivario se hallaba bastante deteriorado cuando se procedió a la reforma.

4. Cierre de una puerta situada en el muro suroccidental y apertura de un nuevo vano para poner en comunicación el espacio basilical con la piscina bautismal.

5. Construcción de una piscina bautismal de tipo cruciforme (fig. 11.2) en el lado S.O. situada en el interior de un recinto de planta cuadrangular (Ramos Sáinz, 1992, 105110). La presencia de un baptisterio entre el mobiliario litúrgico es un denominador común de las iglesias de la Lusitania, tal y como se puede apreciar en La Cocosa; Casa Herrera y 

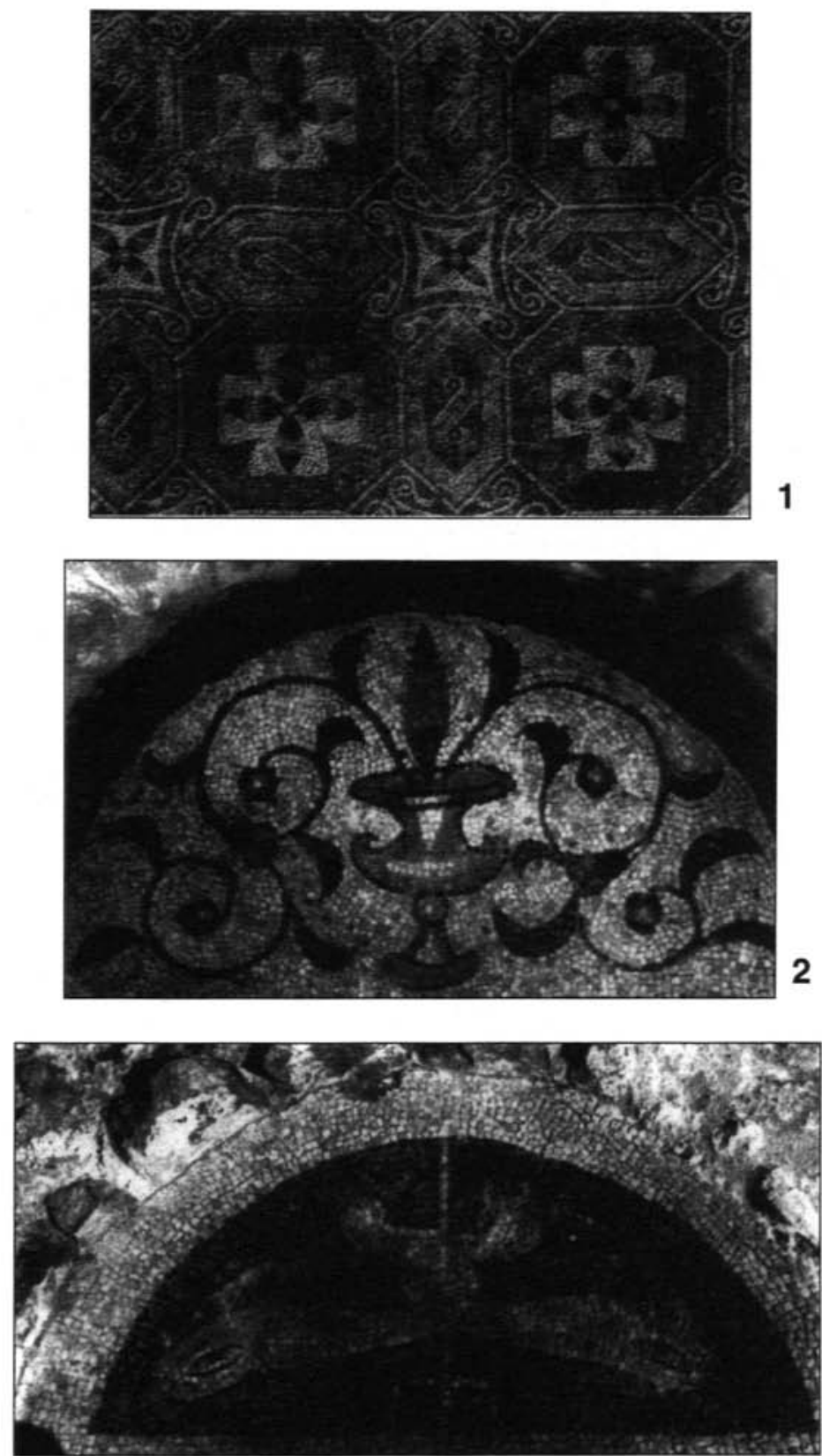

3

Figura 11: 1. Detalle del pavimento musivario del gran salón absidado (mosaico $\left.n^{\circ} 1\right)$. 2. Mosaico $n^{\circ} 1$, ábside lateral izquierdo. 3. Cabecera del mosaico n². 


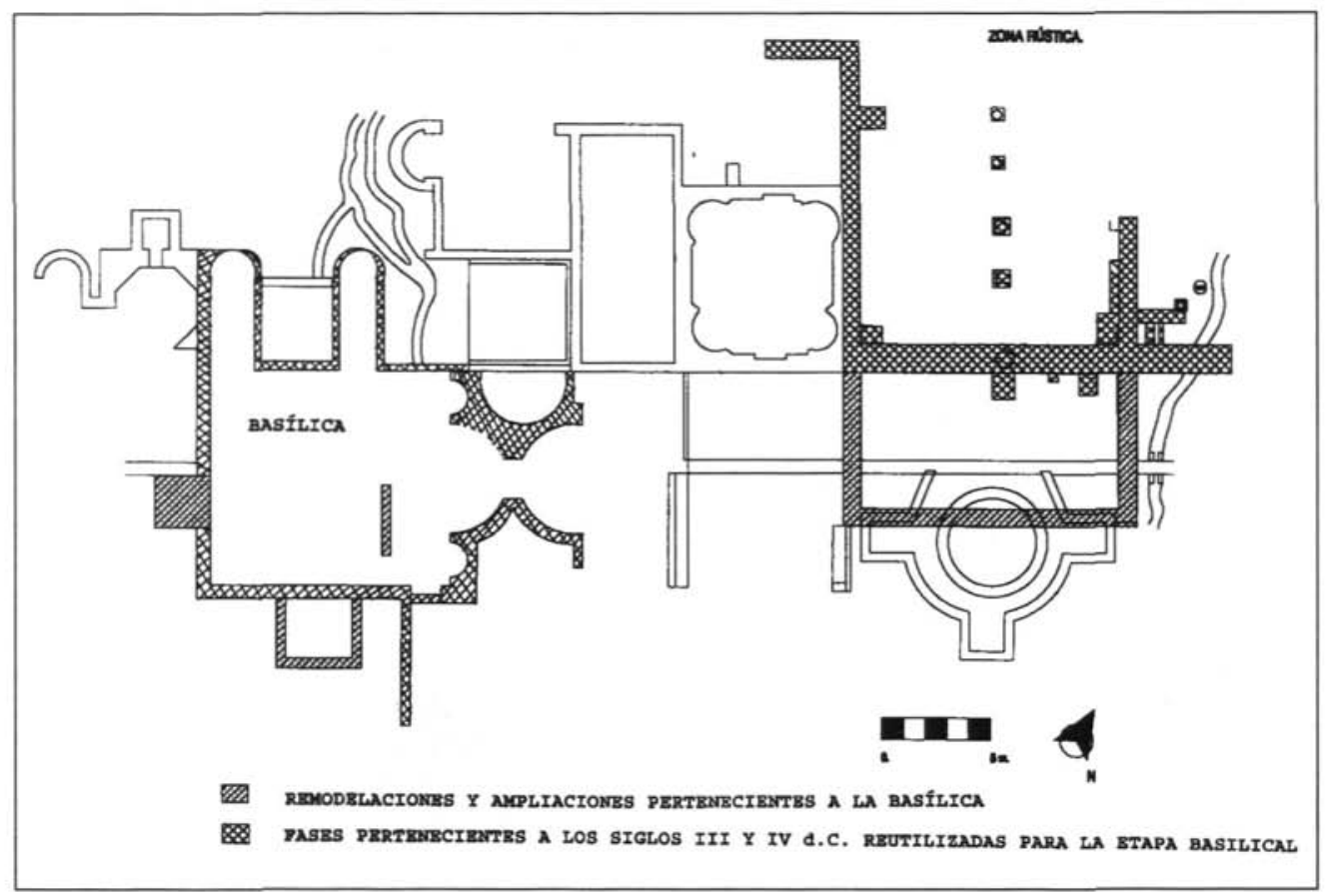

Figura 12. Planta de El Saucedo con ampliaciones y remodelaciones correspondientes a la basilica cristiana.

San Pedro de Mérida (Badajoz) y en el Gatillo de Arriba y Alconétar (Cáceres). La instalación de baptisterios en el ámbito rural parece ser un fenómeno avanzado que se sitúa en el siglo VI, al menos para el Conventus Emeritensis y en el Pacensis. Por último, cabe mencionar que hubo otras reformas que completaron el cuadro de la importante remodelación del lugar para su conversión en Basílica que no especificamos aquí (Castelo et alii, 2000, 94-95).

Fuera de contexto y hallado de forma casual se documentó el altar (Ramos y Castelo, 1992, 121-122) (fig. 13.3). Debió estar situado delante del santuario, directamente asentado sobre el mosaico, sin que haya quedado huella de su colocación. La mesa de altar está prácticamente completa y el tablero pétreo presenta como decoración central un crismón compuesto por las letras $P$ y $X ; A$ y $W$. Junto al monograma, en la parte inferior derecha, aparece grabada una inscripción difícil de interpretar. El hallazgo de este importante elemento del mobiliario litúrgico contribuye a enriquecer el escaso número de ejemplares documentados.

Estamos, por tanto, ante una Basílica de planta rectangular con cabecera cuadrangular, orientada de oeste a este, con entrada situada probablemente entre los dos pasillos y otra secundaria correspondiente a las fauces del antiguo salón, que nunca llegaron a cerrarse. Según las sugerencias realizadas por Cerrillo Martín de Cáceres para la citada basílica de 

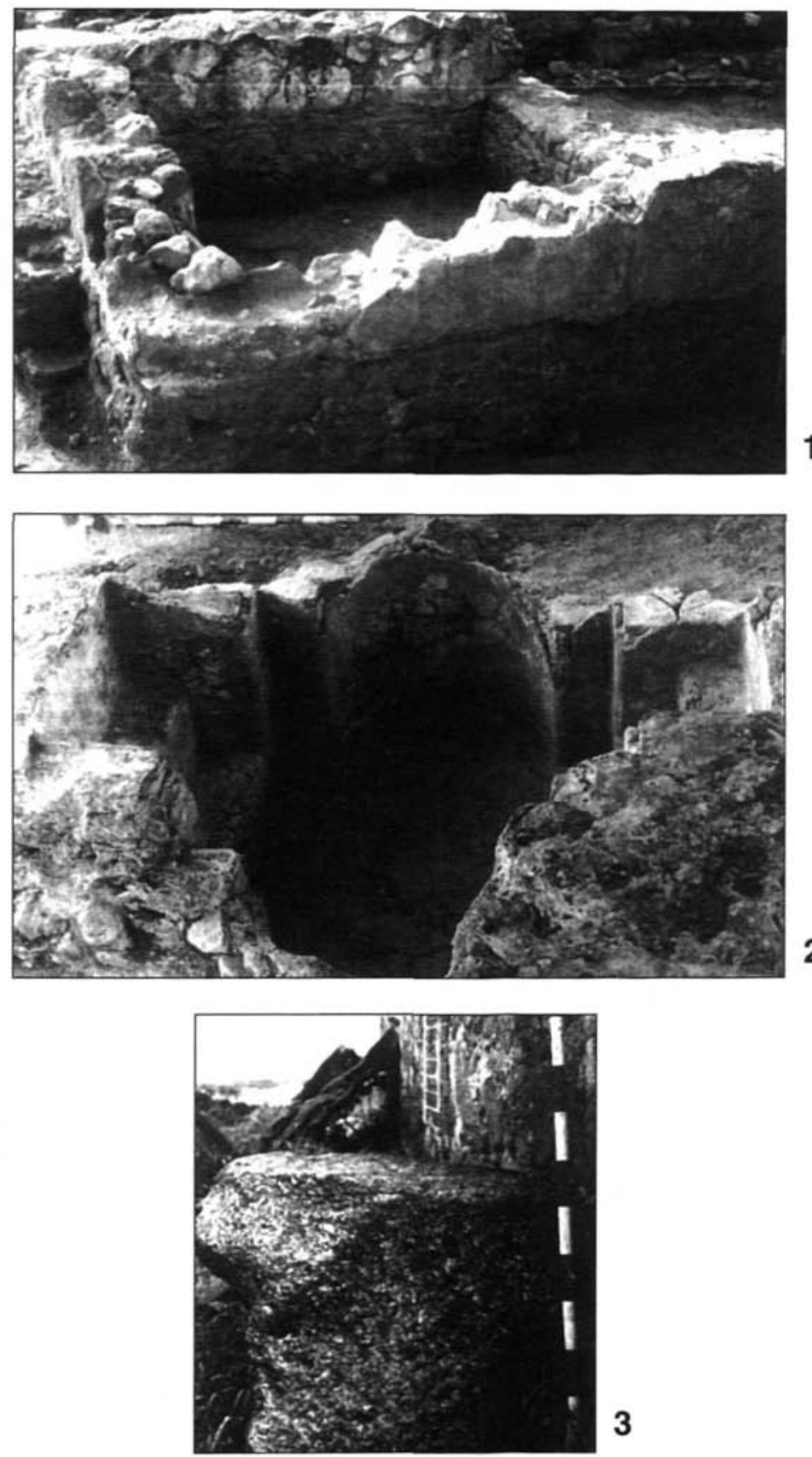

Figura 13: 1. Cabecera de la basilica cristiana, desde el este. 2. Piscina bautismal de la basilica cristiana. 3. Mesa de altar de la basilica cristiana. 

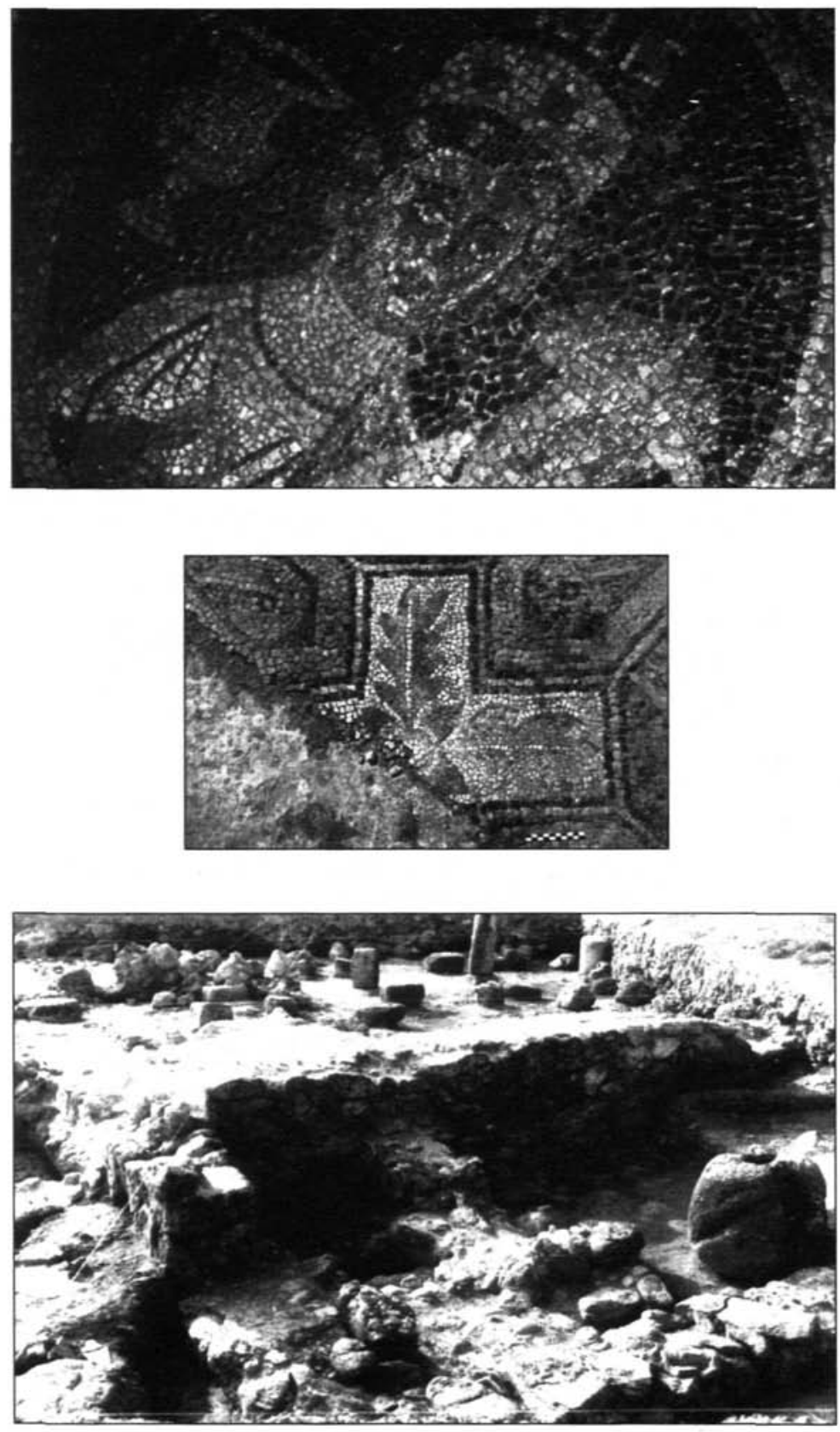

Figura 14: 1. Mosaico $\mathrm{n}^{\circ} 4$, detalle del busto del medallón central, con inscripción ISCALIS. 2. Particular del mosaico $n^{\circ} 1$ : cruz de significado cristiano. 3. Vista general del área fabril, desde el este: en primer término, la prensa, al fondo, el almacén columnado. 
Ibahernando, los muros perimetrales de la basílica de El Saucedo pudieron haber tenido una altura escasa y debieron estar terminados en tapial. La cubierta del santuario, posiblemente abovedada, pudo tener un nivel inferior al de la nave, con el fin de acentuar los volúmenes desde el exterior y permitir la presencia de algún vano a modo de iluminación. El pequeño tamaño de la basílica de El Saucedo no solo se documenta en la iglesia de Ibabernando sino también en Alcalá de los Gazules. Mientras la basílica estuvo en uso, se registraron reformas, obras que empobrecen la prestancia arquitectónica heredada de la villa y recinto termal originario (Castelo et alii, 2000, 95).

La aparición de parroquias rurales es un fenómeno bien documentado no sólo en la Lusitania, sino también en el resto de Hispania. Su presencia constituye una verdadera colonización del territorio con un doble sentido de cristianización y establecimiento de un dominio territorial de carácter eclesiástico por parte de la sede episcopal y, además servirían para aglutinar a las comunidades rurales cristianizadas. La basílica de El Saucedo pudo tratarse, como ha sugerido el Dr. Cerrillo para la iglesia de Ibahernando, de un pequeño edificio de función parroquial con carácter privado. Parroquial, desde el punto de vista que supone la atención religiosa de una pequeña comunidad y privado por hallarse en una propiedad rural. La existencia de iglesias en propiedades particulares es algo demostrado a través de diversas fuentes literarias, como por ejemplo las Actas Conciliares de los siglos VI y VII.

\section{El mosaico de la cabecera de la basílica}

Gracias a la amabilidad del Director del Museo de Santa Cruz de Toledo, D. Rafael García Serrano, se ha podido analizar el pavimento detalladamente. La composición está formada por diversas bandas que forman cuadros y el medallón central presenta fondo negro con busto femenino ataviado de túnica y manto. En la mano derecha sostiene una cornucopia y en la mano izquierda lleva un globo. A la derecha del busto se ha figurado una crátera y sobre la cabeza de la mujer se lee ISCALLIS (fig. 14.1). Entre el medallón central y las bandas ornamentales en disposición cuadrangular quedan cuatro esquinas que se han rellenado con cráteras (Castelo et alii, 2000, 95-96). Nos hemos inclinado a interpretar esta representación femenina como la personificación de Tyché o Fortuna, en esta ocasión, acompañada por dos de sus atributos: la cornucopia y el globo, tal y como aparece representada en algunas monedas. La presencia de està imagen en la cabecera de la basílica podría relacionarse con el culto a las ninfas detectado en las cercanías de El Saucedo.

En Hispania no hay paralelos, al menos conocidos, con fechas tan tardías. La representación de bustos femeninos es frecuente encontrarla en los mosaicos de la Hispania romana entre los ss. II y IV; pero estos han sido interpretados de formas muy diversas y nunca como la personificación de Fortuna (Castelo et alii, 2000, 98). La representación de El Saucedo corresponde a la moda característica del Bajo Imperio, que tiende a suplantar las imágenes mitológicas por representaciones alegóricas o simbólicas (en Oriente, a partir del s. III y hasta finales de la Antigüedad tuvieron gran éxito, al contrario que en Occidente). Estas figuras encajan en las corrientes espirituales de ésta época, patentes en la teología cristiana (Castelo et alii, 2000, 98-99). El pavimento con la representación de la 
Fortuna es un ejemplo más de la abundancia de temas paganos que siguieron siendo representados en todos los campos artísticos, aunque ya hubiera triunfado el cristianismo ${ }^{[1]}$.

El interés de este mosaico radica en muchos aspectos: iconográficos, cronológicos y epigráficos. La inscripción del mosaico fue estudiada por A.M $\mathrm{M}^{\mathrm{a}}$ Canto, plateando sugerentes hipótesis (2001, 118-127).

\section{Área Fabril}

Esta zona estuvo formada por un espacioso patio o corral y un gran ambiente precedido por una zona seguramente porticada y con suelo de tierra batida (fig. 12). El gran ambiente está determinado por muros de notable espesor que definen la estructura arquitectónica principal. Su interior parece configurarse como una gran sala con soportes regularmente repartidos para obtener una especie de sala hipóstila, interpretada como un amplio almacén, porque de tal ha de tratarse a tenor de los materiales que contenía: grandes vasos de almacenamiento, instrumentos agrícolas (rastrillos, hoces, hachas, picos, etc.), cerámica común y de cocina de acabado grosero, restos de animales, escorias, etc. Quedaban restos de pavimentación de baldosas y bancos de adobe y de obra adosados respectivamente a las paredes interiores de los muros. La cubierta pudo ser plana, y tal vez dotada de piso superior.

Al fondo de la supuesta galería exterior y junto al gran almacén se abre una estancia, sólo parcialmente excavada, donde se hallaba una prensa de la que se ha conservado la gran pieza de piedra que le servía de anclaje (fig. 14.3). Por dicha habitación discurre una conducción cubierta con lajas de piedra.

En general los muros de las estancias descritas se apoyan en una recia cimentación de hormigón y piedras. El alzado debía completarse con adobes y ladrillos y todo se revestía con enlucido. Las cubiertas, de estructura de madera claveteada, tenían una capa de arcilla, seguramente para impermeabilizarla, sobre la que descansaban las tejas planas y curvas. Del portaje de éstas estancias se han hallado clavos, argollas, remaches y restos de madera carbonizada. En relación al estudio de los sistemas de cubrición de todas estas estancias, cabe mencionar aquí que se están efectuando diferentes tipos de estudios encaminados a deducir algunas de sus características. El análisis de los clavos y otros materiales de construcción podría aportar datos acerca de los sistemas de anclajes de los armazones y los análisis antracológicos de los restos de vigas carbonizadas, por su parte, proporcionarán la identificación de especies empleadas y, por ende, datos sobre sus longitudes máximas, umbrales de resistencia, etc.

[1] La Dra. Canto realiza una interpretación diferente a la nuestra, cree que "la imagen femenina sostiene un creciente lunar en la mano derecha y con la izquierda el extremo superior de una serpiente con boca abierta al máximo, dejando salir de ella una cornucopia" (Canto, 2001, 119-120). Interpreta la imagen como una personificación tópica, acuática, curativa y fertilizadora (Canto, 2001, 126). 


\section{MATERIALES.}

Los materiales referidos a continuación corresponden a las campañas anteriores a la última realizada en el 2000, por hallarse ésta en proceso de estudio.

\section{A. ACTIVIDADES DOMÉSTICAS. LA VAJILLA, EL ADORNO PERSONAL Y LA VESTIMENTA.}

\section{Cerámicas}

Los estudios sobre producciones cerámicas finas y comunes aparecidas en las distintas fases de ocupación constatadas en El Saucedo no están aún concluidos. Por el momento, se han estudiado las producciones más significativas de terra sigillata altoimperial -s. I d.C.- y bajoimperial -ss. III-IV d.C.- y las cerámicas comunes de época visigoda -ss. V-VII d.C.- (Arribas et alii, 1999).

Época altoimperial (fines s. I comienzos s. II d.C.). Son de escasa cuantía, en relación con el total recogido. Éstas corresponden a una serie de fragmentos que se adscriben a producciones de terra sigillata gálica de buena calidad. Son de destacar aquellos fragmentos que permiten reconstruir tres formas: Drag. 29B (fig. 15.1), Cuenco Drag. 24-25 o Ritt 5 (fig. 15.3) y Drag. 30 (Arribas et alii, 1999). La ausencia de marcas de alfarero, así como la generalización del uso de éstos motivos decorativos dentro de las producciones galas, no permiten definir los talleres propios de fabricación, aunque debido a las características que presentan, es muy posible que se trate de producciones salidas de los talleres de La Graufesenque, más activos comercialmente y con mayor presencia en los mercados hispanos interiores que los talleres de Montans. En el valle del Tajo, no son muy numerosos los hallazgos de ejemplos de estas producciones (Arribas, Castelo y Bendala, 1999, 308309).

Dentro de las cronologías propuestas a través del estudio de la cerámica gálica, debemos citar varios fragmentos, que permiten reconstruir una forma correspondiente a producciones cerámicas de paredes finas. Se trata de un vaso de forma Mayet 37 ó 43 (fig. 15.2). La cronología de estas piezas se podría encuadrar entre los gobiernos de Tiberio y Claudio, épocas de mayor actividad de estos talleres.

Bastante mejor se conocen las producciones de terra sigillata bispánica de época altoimperial que aparecen en la península debido a la instalación en Hispania de diversos talleres, como consecuencia de la popular expansión de las vajillas de mesa de tipo terra sigillata, a partir del siglo I d. C., perdurando en su producción hasta finales del II d. C. En general, dentro de los fragmentos recogidos en El Saucedo se pueden establecer dos tipos básicos de producciones: las producciones de talleres riojanos, con los dos centros de Tricio y Bezares y de talleres de Andujiar (Arribas et alii, 1999, 309). En las primeras se ha comprobado la presencia de la forma Drag. 29 y 37 y en las decoraciones distintos estilos (según Mezquiriz). 


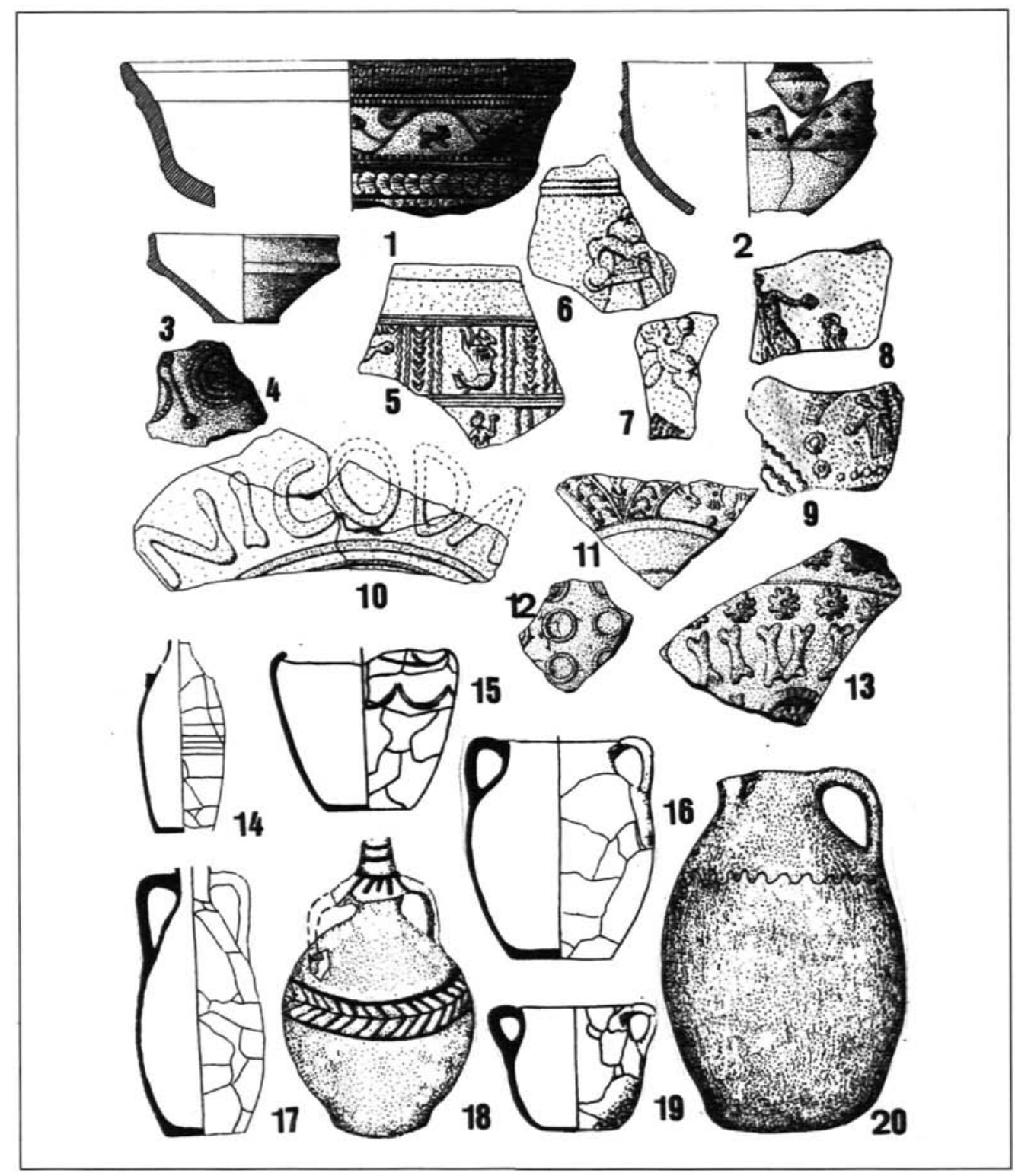

Figura 15. Piezas cerámicas: Terra sigillata gálica Drag. 29B ( $\left.\mathrm{n}^{\circ} 1\right)$, Paredes finas, Mayet XXXVII ó XLIII ( $\left.{ }^{\circ} 2\right)$, Terra sigillata gálica Drag. 24/25 ó Ritt. 5 ( $\left.\mathrm{n}^{\circ} 3\right)$, T.S.Hispänica altoimperial, estilo de círculos $\left(\mathrm{n}^{\circ} 4\right)$,

T.S.Hispánica altoimperial con motivo de separación de metopas ( $\mathrm{n}^{\circ}$ 5), T.S.Hispánica altoimperial, con decoración figurada ( $\mathrm{n}^{\circ} 6$ a 9), T.S.Hispánica altoimperial, con decoración epigráfica $\left(\mathrm{n}^{\circ}\right.$ 10), T.S.Hispánica Tardías ( $\mathrm{n}^{\circ} 11$ a 13), cerámica común, botellas de dos asas $\left(\mathrm{n}^{\circ} 14\right.$ y 17$)$, olla con borde vuelto hacia dentro $\left(n^{\circ} 15\right)$, ollas con dos asas de borde vuelto hacia fuera ( $n^{\circ} 16$ y 19), jarra de cuello moldurado y engrosado $\left(n^{\circ} 18\right)$, jarra de boca trilobulada $\left(n^{\circ} 20\right)$. 
En cuanto a las decoraciones, se destacan: El estilo decorativo de imitación gálica (mediados del s. I d. C.); las series de metopas en las que se representan motivos figurados humanos, animales y vegetales (estilo utilizado durante el siglo II d.C) (figs. 15.5 a 15.9); los diseños circulares concéntricos que caracterizarán el siglo II d. C. (fig. 12.4); el estilo de series de círculos, coetáneo del anterior aunque preponderante a partir del siglo II d. C. (fig. 15.12) y el burilado, datado desde mediados del siglo I hasta mediados del s. II d. C. (Arribas et alii, 1999). Por último, hay que mencionar la existencia dentro del conjunto de materiales estudiados, de una marca de alfarero en la que se lee (...) RONTN, marca que puede corresponder a los alfareros FRONTINUS PATERNUS o C. FRONTINUS. El primero, podría haber sido alfarero del taller de Bezares y el segundo de Arenzana de Arriba, dentro de la misma área de producción. (Arribas, Castelo y Bendala, 1999, 311). En cuanto a las producciones de los talleres de Andújar, éstas tienen una representación menor en el yacimiento de $\mathrm{El}$ Saucedo. Entre los fragmentos recuperados se seleccionaron cuatro ejemplares que remiten a un tipo de producción especial que presenta como motivos decorativos composiciones realizadas con letras a molde. Uno de ellos conserva gran parte de una inscripción en la que se puede leer NICODA (fig. 15.10) y otros de menor tamaño presentan varias combinaciones de letras entre las que se puede reconocer $L A ; I T$; o $A R$. Es también interesante destacar la presencia de dos fragmentos en las que las series de letras se combinan con círculos, y que pueden tener sus paralelos en un ejemplar procedente de Talavera de la Reina y adscrito al centro productor documentado en esta ciudad (Arribas et alii, 1999, 311).

Época bajoimperial (fines del III comienzos del IV d. C.). Los fragmentos cerámicos de terra sigillata hispánica pertenecientes a El Saucedo forman el conjunto más amplio dentro del total cerámico recogido. Entre los ejemplos se encuentran bien representados distintos estilos decorativos: rosetas y series de círculos concéntricos; grandes círculos rellenos de series de ángulos o series de rosetas alternando con series de bastones (fig. 15.13) y circulos con rosetas inscritas. Por último, hay que hacer mención a la existencia de una decoración característica: motivos vegetales estampados (fig. 15.11) (Arribas et alii, 1999, 313).

Tardoantigüedad (siglo V-VIII d. C.). La cerámica común documentada para esta etapa tardía de finales del siglo V al VIII se caracteriza por presentar las superficies rugosas al tacto y las paredes exteriores simplemente alisadas o con ondulaciones/estrías profundamente marcadas en el torno o hechas a peine. Éstas cerámicas suelen reproducir formalmente tipos tradicionales del Alto y Bajo Imperio pero con unas características técnicas y algunas innovaciones formales que permiten individualizarlas con respecto a los modelos anteriores. Las cerámicas tardoimperiales de época visigoda se caracterizan por la uniformidad de tipos, a pesar de la diversidad de detalles en las formas concretas que las hacen distintas (Arribas et alii, 1999, 315).

- En el caso de El Saucedo se documentan ejemplares cerámicos pertenecientes a la vajilla de cocina:

- ollas con borde vuelto hacia afuera con asas y sin ellas (Grupo I de Vegas y Forma 3 de Benito Izquierdo) (fig. 15.16 y 15.19). Comienzan su desarrollo a partir del siglo II a. C. pero perviven manteniendo sus rasgos hasta época bajoimperial, entrando incluso en la 
Edad Media (Arribas et alii, 1999, 316); ollas con borde vuelto bacia dentro (Grupo 3 de Vegas). Su cronología es muy amplia pero será en el bajo Imperio cuando éstas vasijas sean más numerosas (Arribas et alii, 1999, 316-317); cuencos con dos asas. La mayoría de los tipos se encuentran anclados en tradiciones formales y funcionales que arrancan desde los primeros momentos de la producción cerámica (Arribas et alii, 1999, 317); cuencos con pitorro (Tipo 11 de Vegas y 26 de Gutiérrez). Su uso se generalizará en el periodo tardoimperial. La forma se ha documentado tanto en cerámica común como en terra sigillata bispánica tardía (forma 43) y en sigillata gálica tardía. Suelen aparecer en estratos del siglo IV d. C. aunque no faltan ejemplos constatados para el siglo V y VI d. C.

- También se han documentado vasos pertenecientes a la vajilla de mesa:

- jarras de cuello moldurado y engrosado con una o dos asas (Tipo 42 de Vegas) (fig. 15.18). Se constatan desde épocas muy tempranas perdurando en época tardo imperial y visigoda. Diversos autores consideran que estas piezas proceden de la terra sigillata clara $C$ y que llegarían a Hispania a través de las perduraciones narbonenses. Sin embargo se produce el hecho de que esta forma es mayoritaria en la sigillata bispánica y rara vez se ejecuta en la Narbonense. Abascal Palazón la define como forma 21 y la considera una imitación de la forma Palol-Cortés 14 de terra sigillata bispánica tardía (Arribas et alii, 1999, 317-318); botellas de dos asas (fig. 15.14 y 15.17); jarras de boca trilobulada (Tipo 46 de Vegas y 15 de Izquierdo Benito) (fig. 15.20). El tipo es muy homogéneo y se puede encontrar con cronologías muy avanzadas sin apenas variaciones formales (Arribas et alii, 1999, 318).

Las decoraciones documentadas en las piezas de este yacimiento consisten en incisiones simples; incisiones múltiples onduladas o quebradas. Los motivos decorativos representados son de tradición antigua y enlazan con lo romano.

El estudio y análisis de los materiales cerámicos proporcionan una serie de datos y conclusiones que ilustran la importancia y desarrollo de este establecimiento agropecuario durante las épocas romana y visigoda. Los recipientes de mayor tamaño sin decoración se interpretan como vajilla de cocina y almacenamiento, mientras que las botellas piriformes y las que tienen decoración pintada tendrían una función simbólica-ritual asociadas a la basílica (Fernández, 1987). La visión proporcionada por el estudio de las fases de construcción y ocupación junto con los materiales cerámicos pertenecientes a cada una de ellas, muestra el gran arco cronológico (ss. I d. C. a VIII d. C.) durante el que este complejo rural estuvo habitado.

\section{VIDRIO}

Las formas que han podido ser identificadas corresponden a la vajilla usual durante este periodo en Hispania (vasos, copas, cuencos, jarras, platos, etc.), además de objetos para el aderezo personal, como pulseras, un colgante, ungüentarios y un removedor de perfumes, vidrio de ventana, así como elementos decorativos, como es el caso de teselas vítreas. La mayor parte de ellos estuvieron en uso de fines del s. III o inicios del s. IV hasta 
finales de esta centuria. Hasta el momento algunas publicaciones han avanzado los resultados de este estudio (Torrecilla, 1999; $i d$., e.p.a; $i d$. ., e.p.b).

La distribución de formas de vajilla vítrea entre los dos periodos de El Saucedo son los siguientes:

1. En la segunda mitad del s. I y el s. II se emplearon tanto botellas, copas (Is. 12) (fig. 13.1), como cuencos (Is. 2, 3 y 44) (fig. 16.2 y 16.3) de distintos tipos, tapaderas (Is. 66) y ungüentarios (Is. 11) (fig. 16.4), aunque obviamente no podemos considerar estas piezas como representativas del total.

2. A partir del s. IV predominan las formas para beber junto con los cuencos (Is. 96, 116, 117 y M. J. 88) (fig. 16.15), vasos (Is. 106 y poligonales) (figs. 16.5 a 16.8), copas (Is. 34, 109 y 112 ó 117) (figs. 16.11 a 16.13), botellas (Is. 102), jarras (Is. 120), así como platos (Is. 47 y 97) (fig. 13.14), ungüentarios (Is. 28, 67, 68 y 82) (figs. 16.16 a 16.18). Las formas más comunes de época tardía suponen desde el s.III una evolución de tipos existentes en época altoimperial hacia nuevas formas. Los recipientes más abundantes son los cuencos, de los cuales el tipo más común es el cuenco Is. 116. Le siguen en cantidad los vasos y las copas. Otros elementos de la vajilla son menos abundantes, como es el caso de las botellas y de los jarros, aunque es extraña la falta de platos, de los que se han identificado sólo 2 ejemplares.

Si bien abundan más en $\mathrm{El} \mathrm{Saucedo} \mathrm{las} \mathrm{formas} \mathrm{lisas,} \mathrm{muchas} \mathrm{de} \mathrm{ellas} \mathrm{se} \mathrm{hallan} \mathrm{deco-}$ radas de forma llamativa. Las decoraciones que presentan algunos de los vasos vítreos son muy características en el Bajo Imperio y la Tardoantigüedad: líneas incisas; aplicación de hilos en caliente, incluso de distinto color (azul o blanco); molduras en relieve; mamelones; decoración de panal; así como un ejemplar de epigrafía decorativa, una "A" bajo el borde de un cuenco o vaso.

Durante las excavaciones de El Saucedo se han recuperado algunas escorias de vidrio, que nos indican la posible presencia de un horno propio, incluso de una officinae vitreorum, aún no localizado, que produciría piezas para el uso interno de la vivienda, acorde a la realización de numerosas actividades de carácter artesanal en la pars rustica, que le permitirían ser hasta cierto punto autosuficiente.

Otros elementos vítreos, que no forman parte de la vajilla propiamente dicha, y tienen funciones muy diversas son varios ejemplares de pulseras (fig. 16.19) realizadas en vidrio opaco negro, de sección semicircular y circular, una de ellas decorada exteriormente con una serie de incisiones transversales y paralelas. También un colgante vítreo (fig. 16.20), compuesto de un tubo cónico de vidrio negro opaco, en cuyo extremo se enrolló un hilo vítreo de color rojo. Resulta de gran interés, pues son muy escasos los paralelos documentados en Hispania. Existe un ejemplar idéntico en la "Casa de Hyppolitus" de Complutum, con los mismos colores y disposición, fechado en el s. IV (AA.VV. 1998, 256, 202); otro muy similar procede de la tumba 9 de Albalate de las Nogueras (Cuenca), así como en Sasamón (Fuentes 1989, 49 y 88, fig. 12 y lám. XVI). Parece ser que estos colgantes se vendían como colgantes fálicos, que servían para alejar el "mal de ojo" o Indivus, relacionados con las Bullae Praetextae y que como amuletos parecen ser comunes desde los ss. II y III (AA.VV. 1998, 202, 256; Fuentes, 1989, 88-89). 

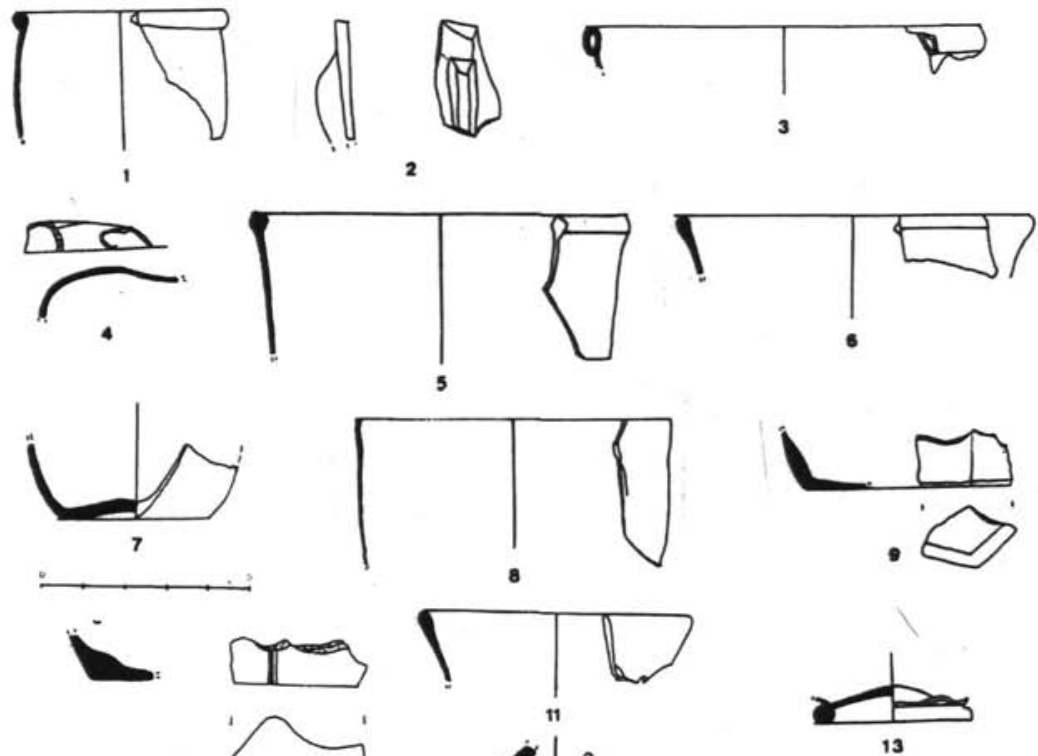

10
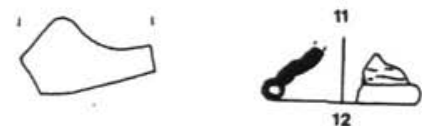

13
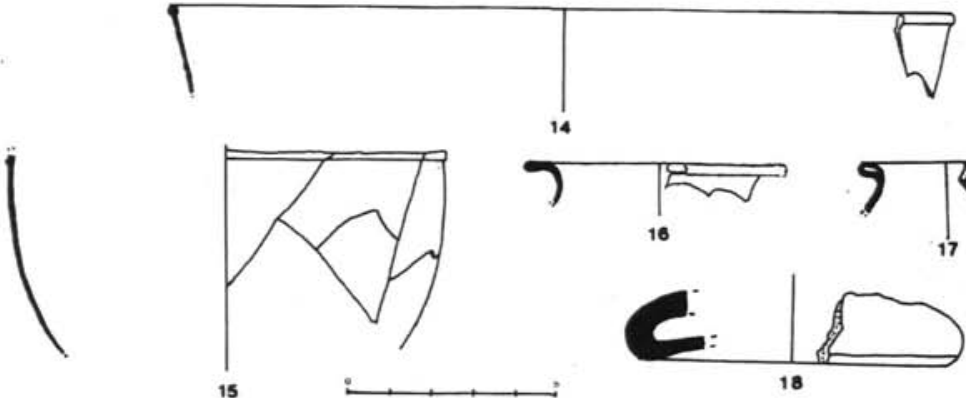

15
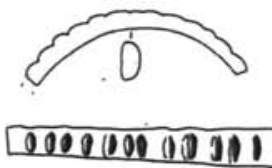

19
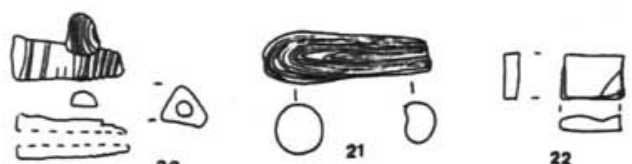

Figura 16. Vidrio altoimperial: vaso o cuenco Is. $12\left(\mathrm{n}^{\circ} 1\right)$, cuenco de costillas Is. $3\left(\mathrm{n}^{\circ} 2\right)$, cuenco Is. $44 \mathrm{a}$ $\left(n^{\circ} 3\right)$, y ungüentario Is. $11\left(n^{\circ} 4\right)$. Vidrio tardío: vaso Is. $106 \mathrm{a}\left(\mathrm{n}^{\circ} 5\right)$, vaso Is. $106 \mathrm{~b}\left(\mathrm{n}^{\circ} 6\right)$, vaso Is. $106\left(\mathrm{n}^{\circ} 7\right)$, vaso Is. $106 \mathrm{c}\left(\mathrm{n}^{\circ} 8\right)$, vasos poligonales ( $\mathrm{n}^{\circ} 9$ y 10), vaso o copa $\left(\mathrm{n}^{\circ} 11\right)$, pie de copa Is. $109 \mathrm{~b}\left(\mathrm{n}^{\circ} 12\right)$, pie de copa Is. $34\left(n^{\circ} 13\right)$, plato Is. $97\left(n^{\circ} 14\right)$, cuenco Is. $96 a\left(n^{\circ} 15\right)$, ungüentario Is. $67\left(n^{\circ} 16\right)$,

ungüentario Is. $68\left(n^{\circ} 17\right)$, ungüentario Is. $82\left(n^{\circ} 18\right)$, pulsera $\left(n^{\circ} 19\right)$, colgante fálico $\left(n^{\circ} 20\right)$, removedor de perfumes $\left(\mathrm{n}^{\circ} 21\right)$. Tesela $\left(\mathrm{n}^{\circ} 22\right)$. 
También se ha documentado un removedor de perfumes en forma de gota (fig. 16.21); cinco fragmentos de vidrio de ventana; una tesela vítrea incolora (fig. 13.22), cuyo como decoración arquitectónica se hizo usual a partir de mediados del s. I a.C. como un elemento de lujo; y vidrio decorativo de pared, formado por 2 placas planas de color azul, una azul verdosa, otra verde azulada, unidas entre sí.

\section{BRONCES}

Son frecuentes los hallazgos de objetos realizados en bronce durante las campañas de excavación. Las técnicas de fabricación empleadas, como fundido, cincelado o modelado no distan mucho de las utilizadas para el trabajo de otros metales requiriendo de mano de obra especializada, y sus propiedades permiten su utilización para un mayor y variado tipo de objetos. Por otro lado, el habitual proceso de reciclaje sufrido por los objetos de bronce hizo que, a menudo, éstos se reutilizaran mediante un nuevo trabajo de fundición, de modo que pudiera realizarse con el mismo material otro objeto diferente más acorde con la moda del momento o simplemente más utilitario según las necesidades de su propietario.

La datación de los materiales viene marcada fundamentalmente por su tipología, siendo posible en la mayoría de los casos encontrar paralelos en otros yacimientos tanto del mismo área como de lugares alejados geográficamente. Hemos de contar, asimismo, con que muchos de estos objetos tienen una larga tradición en el tiempo o que su simplicidad formal hace difícil dar una cronología exacta, por tanto, en muchos casos viene determinada por su relación con otros materiales aparecidos junto a ellos.

La variedad de objetos de El Saucedo es tan amplia que sería interminable la enumeración detallada de los mismos pero podemos establecer una división basada en su funcionalidad:

1. Vida Cotidiana: Fragmento de recipiente con decoración incisa, tapadera (fig. 14.2), remaches (figs. 17.3 y 17.4), anillas de suspensión, punzón, varilla, aretes, haz de láminas, placa con remache, borde de recipiente, pasador, anzuelo. La cronología de estas piezas romana-tardorromana.

2. Adorno y Arreglo personal: remache decorativo, botón, fibula en Omega (s. I a.C.- tardorromana.) (fig. 17.8), fragmento de pulsera (cronología romana-tardorromana) (fig. 14.1), fragmento de fibula, anillos (cronología romana-tardorromana) (figs. $17.5 \mathrm{y}$ 17.6), fibula Aucissa (s. I-II d.C) (fig. 17.7).

3. Objetos Rituales: Asa de pátera (cronología tardorromana) (fig. 17.11).

Otro conjunto significativo de piezas de la vajilla halladas en El Saucedo son los apliques de asa de situlae con decoración antropomorfa. Las piezas de El Saucedo son tres ejemplares, aunque responden a dos tipologías distintas: La primera pieza consta de un escudo triangular decorado con un rostro humano (nariz, ojos y boca con una amplia sonrisa), y delimitado por una serie de incisiones verticales paralelas en disposición radial. Sobre un 


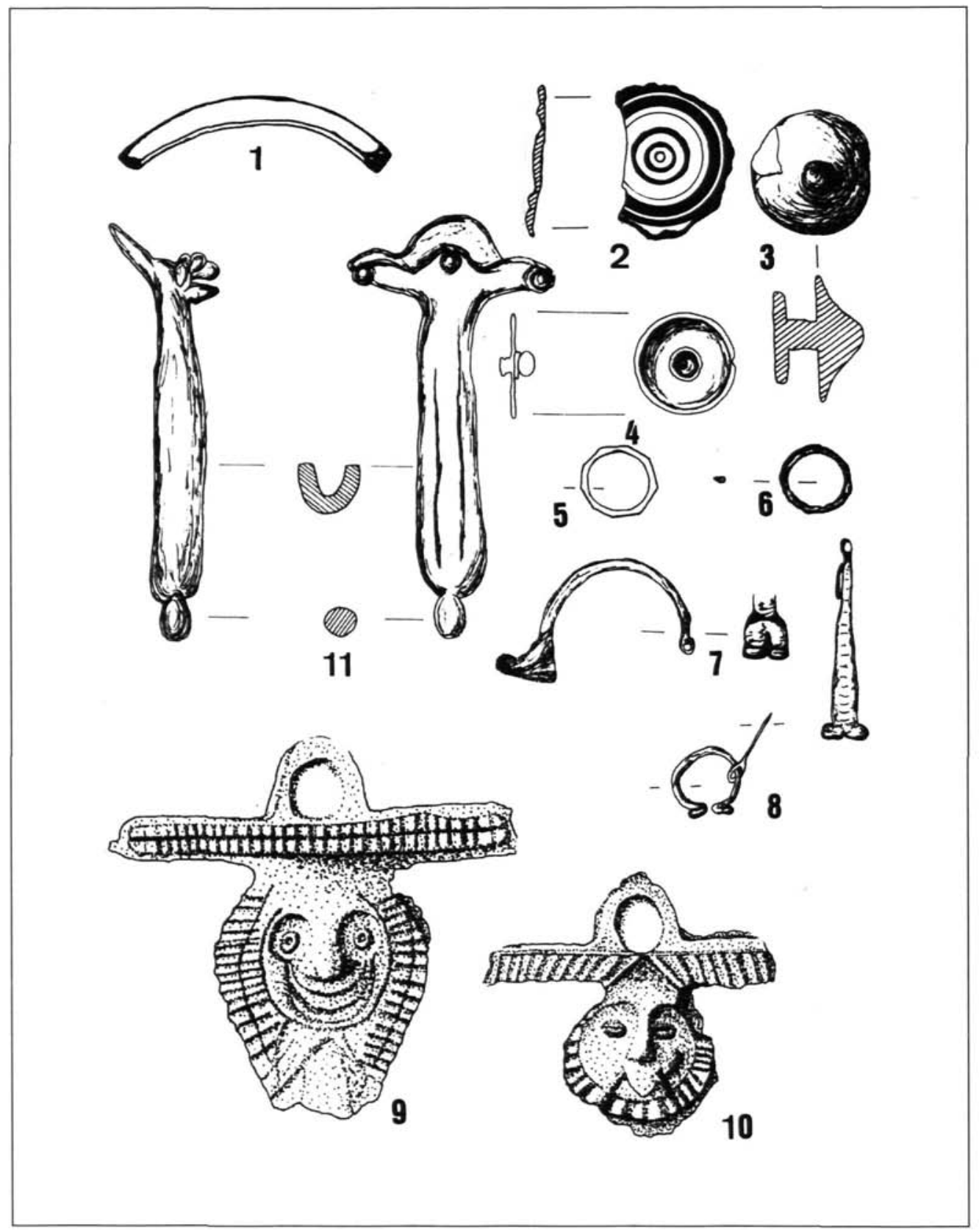

Figura 17. Elementos de bronce: fragmento de pulsera $\left(n^{\circ} 1\right)$, tapadera $\left(n^{\circ} 2\right)$, remache botón $\left(n^{\circ} 3\right)$, remache $\left(n^{\circ} 4\right)$, anillos $\left(n^{\circ} 5\right.$ y 6 ), fíbula aucissa $\left(n^{\circ} 7\right)$, fibula en omega $\left(n^{\circ} 8\right)$, aplique de asa de situla de tipo II ( $\left.{ }^{\circ} 9\right)$, aplique de asa de situla de tipo $\mathrm{I}\left(\mathrm{n}^{\circ} 10\right)$, asa de pátera $\left(\mathrm{n}^{\circ} 11\right)$. 
travesaño decorado por dos molduras se sitúa la anilla. Dadas sus características puede incluirse en el tipo II establecido por M. Delgado para las piezas de Conimbriga. Las restantes piezas constan de un escudo circular decorado con un rostro humano (nariz, ojos, boca y un bigote). Está delimitado por una corona circular radial decorada mediante incisiones verticales paralelas. Sobre un travesaño decorado con incisiones en "V" y verticales se sitúa la anilla. Por sus características pueden adscribirse al tipo I establecido por M. Delgado para los ejemplares documentados en Conimbriga.

El estudio realizado (Castelo et alii, 1995) ha dado como resultado el poder afirmar que el prototipo de los apliques de El Saucedo es originario de la Lusitania, ya que muestran un estilo original que no parece haber sido exportado fuera de las fronteras peninsulares y son perfectamente diferenciables del resto de Europa, pudiéndose poner la decoración figurada en relación con las representaciones de personajes mitológicos del círculo báquico.

\section{MATERIALES EN HUESO TRABAJADO}

En El Saucedo los objetos encontrados se reducen a dos grandes grupos: los útiles de adorno personal y cosmética, y los elementos de decoración de mobiliario. Por lo tanto, se asocian principalmente con el mundo de las actividades femeninas de ámbito doméstico. Todos estos materiales son de cronología bajoimperial (III-IV d.C) y la mayoría aparecieron en la zona identificada como "basurero".

Nuestro estudio incluye la descripción y catalogación de las mismas, el análisis comparativo de corte arqueológico y el avance interpretativo de su funcionalidad (Aguado et alii, e.p. c).El conjunto de piezas se compone de:

- Acus Crinales (fig. 18.7): era uno de los útiles más característicos del adorno personal femenino, el mundus muliebris, en época romana. Todas ellas poseen una decoración muy elemental, referida a la forma de la cabeza. Es probable que fueran fabricadas en El Saucedo.

- Ligula (cucharilla) (fig. 18.3): Se trata del fragmento de una pequeña cucharilla (la parte de la cazoleta), para cosméticos o preparación de productos farmacéuticos.

- Mango de útil (fig.18.5): Enmangue que presenta motivos geométricos, líneas paralelas alternas con retícula romboidal. Posiblemente, se trate del mango para un espejo de bronce.

- Plaquetas decoradas: Se trataría de plaquetas para decorar mobiliario. La primera es una placa rectangular de hueso delgada, con un orificio central unido a otro de menor diámetro, decorada con dos figuras de pez dispuestas en dos líneas convergentes (fig. 18.6). Este tipo de plaquetas son identificadas como elementos decorativos de mobiliario, puede que pertenezca a una arqueta. Su cronología (s.IV-VII d.C) y decoración nos hace pensar que tal vez este dotada de una simbología especial en el culto cristiano (la figura de Cristo). La segunda es una placa de marfil con un orifico circular en uno de los extremos que habría 


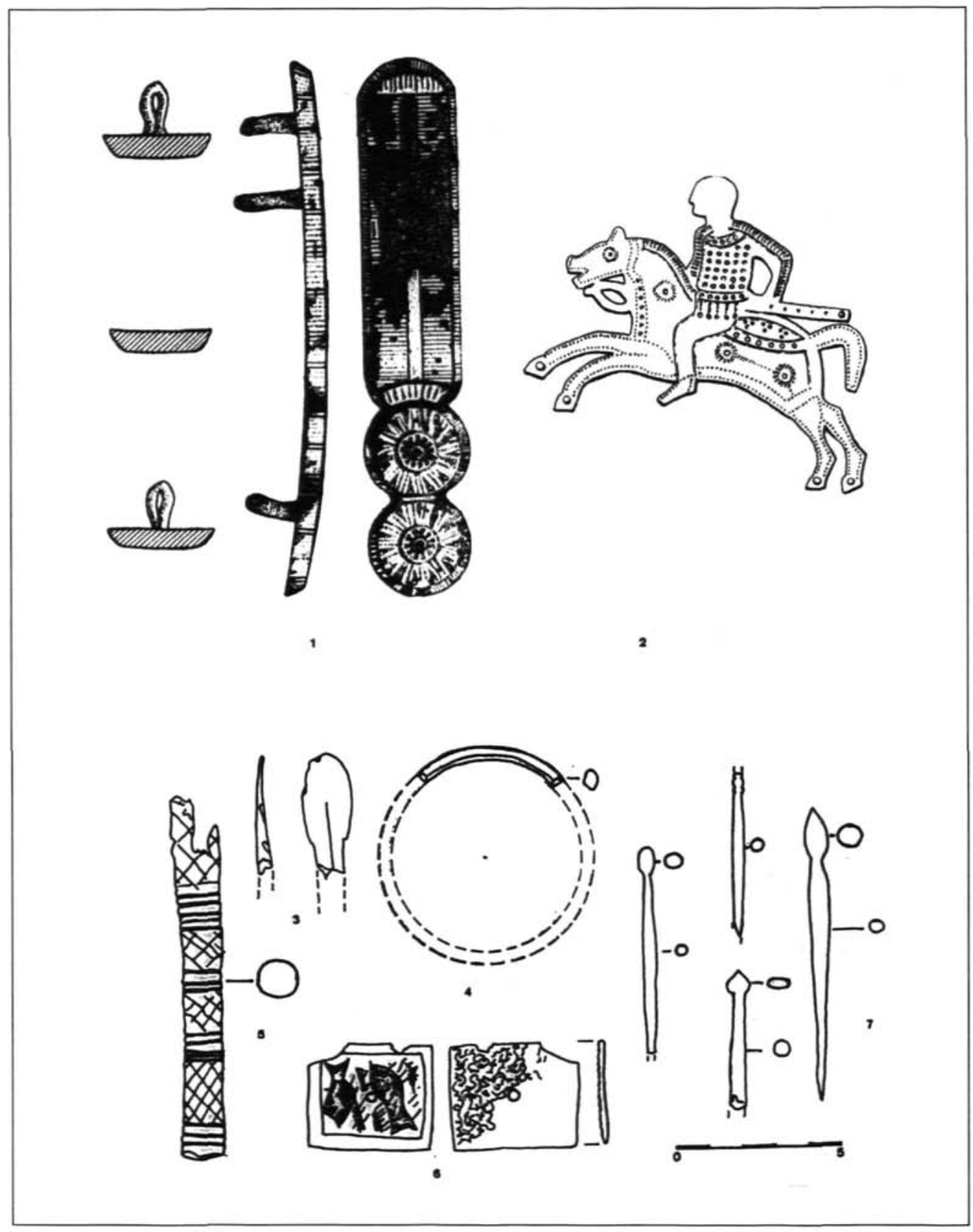

Figura 18: 1. Placa de cinturón múltiple hispano-visigoda; 2. Dibujo de una placa decorativa de un escudo hallada en Stabio (Kt. Tessin, Suiza); 3. Ligula o cucharilla en hueso; 4. Fragmento de pulsera en hueso; 5. Mango de útil en hueso. 6. Placa de hueso decorada; 7. Conjunto de acus crinales en hueso. 
permitido sujetarla o colgarla, decorada con círculos de pequeño diámetro por ambas caras. La tercera y última es una placa de forma rectangular con molduras en los laterales y marcas semicirculares que atraviesan la pieza en sentido transversal, en uno de los extremos.

- Fragmento de pulsera (fig. 18.4): Estamos ante un fragmento de varilla curva de sección aplanada con una ligera angulación en la cara interna. Está fracturada y quemada.

- Prendedor de ovillo: Fragmento de hueso largo trabajado y pulido para conseguir una punta, conservando la acanaladura interna, pero a juzgar por Ponte (1978), para el caso de Conímbriga, se trataría de un alfiler-prendedor a medio fabricar.

\section{Placa de Cinturón múltiple}

Entre los elementos de vestuario, hay que destacar el hallazgo de una placa de cinturón múltiple hispano-visigoda (fig. 18.1 y 18.2)). La pieza que nos ocupa está formada por un cuerpo macizo de hierro forjado cuya superficie presenta una decoración damasquinada realizada en plata y latón. De forma alargada tiene un remate semicircular en la parte superior y dos apéndices circulares en la zona inferior (Sasse et alii, 1995a y b).

Se trata de una pieza única en la Península Ibérica, cuyos paralelos más próximos se encuentran en el sur de Alemania, Suiza y Norte de Italia. Así, su paralelo tipológico más cercano es el que procede de la necrópolis de München-Pasing (Baviera) y gracias a él hemos podido reconstruir la decoración de nuestra pieza. No ocurre lo mismo a través del análisis tecnológico, que aproxima nuestra placa a las documentadas en Chiusi (Italia Longobarda).

Los estudios han podido determinar que este tipo de placa siempre aparece asociada a otras de diferentes formas, dando lugar a un cinturón múltiple que servía para guardar el arma principal: el puñal denominado Sax. En concreto, la placa de El Saucedo se correspondería con una de las verticales que conforman el conjunto de tres placas atribuibles a todo cinturón múltiple. La decoración damasquinada nos conduce a pensar en un propietario de alto status -un jinete-, como bien demuestra la frecuencia con la que son depositados en sepulturas de hombres con ajuares ricos en la Europa Central en el periodo en cuestión, pertenece a un grupo de cinturones que puede fecharse a finales del siglo VII o inicios del VIII.

La aparición de esta pieza en el yacimiento, ya sea por la llegada de un funcionario militar procedente de Centro-Europa ya sea por la existencia de un taller que elaborara este tipo de cinturones o por su introducción a través del comercio, es un elemento determinante para conocer la población de El Saucedo. 


\section{B. ACTIVIDAD ECONÓMICA: EL TRABAJO Y EL COMERCIO.-}

\section{ÚtTIEs DE HIERRo}

En El Saucedo se presta especial atención al conocimiento de las actividades económicas desarrolladas en las diferentes fases de ocupación del yacimiento. Este trabajo, por el momento, se está llevando a cabo a través del análisis de un conjunto concreto de elementos de la cultura material del yacimiento, el de los objetos de hierro (Aguado Molina y Jiménez Cañizos, 1999). La atención se centra primordialmente en la identificación morfológica de los útiles a fin de determinar su funcionalidad, para lo cual, tanto los paralelos arqueológicos como etnográficos han demostrado ser eficaces herramientas. De igual modo, la ubicación de los diferentes ambientes de trabajo constituye otro foco de atención, por lo que se ha tratado de avanzar en la relación existente entre los objetos hallados y las estructuras arquitectónicas descubiertas.

El estado de conservación de los objetos es bueno, aunque determinadas piezas especialmente significativas han sido sometidas a tratamientos de limpieza y consolidación. Los útiles estudiados se ha clasificado en base a 2 criterios distintos: funcional y morfológico:

\section{Clasificación Funcional:}

De entre los Útiles Agrícolas destacan hoces y numerosas plaquitas (fig. 19.4); podaderas; podadera con hachuela (fig. 16.2); podadera sencilla; y corquetes (figs. $19.1 \mathrm{y}$ 19.3).

Los Útiles ganaderos encontrados son cencerros. Se han hallado dos completos de pequeño tamaño que, dadas las dimensiones, hemos considerado pertenecientes a ganado ovicaprino (fig. 19.6), así como un cencerro de mayor tamaño, "campanilla" (según la tipología establecida por Klemm, citado por González, 1996) y el badajo suelto de otro. La "campanilla" sería un tipo de cencerro característico del ganado bovino. Igualmente, hay que mencionar que en la mayoría de las ocasiones los cencerros se sujetaban al cuello del animal mediante collares de cuero provistos de hebillas de hierro (González, 1985) por lo que, tal vez, las hebillas halladas en la misma zona de excavación que los propios cencerros puedan haber pertenecido a collares de ganado, dada su tosquedad y ausencia de decoración. Argollas de doble vástago, posiblemente vinculadas a la necesidad de atar las caballerizas en las cuadras, como queda reflejado en distintas referencias etnográficas. Las Tijeras (fig. 19.5) serían para el esquilado de la lana de oveja, que los paralelos etnográficos así corroboran (González, 1985 y Mingote, 1990). No obstante, otros como Pla Ballester (1969) las asocian al corte de textiles o cuero. Las tijeras que conservamos completas son de pinza sin resorte, el resto son tan sólo hojas sueltas de diversos tamaños.

En cuanto a los Útiles textiles, destacamos el hallazgo de una cardadora de lino (fig. 19.7). Empleada para la preparación de la fibra textil, consiste en un taco de madera en el que se insertan un conjunto de varillas delgadas y acabadas en punta unidas entre sí en 


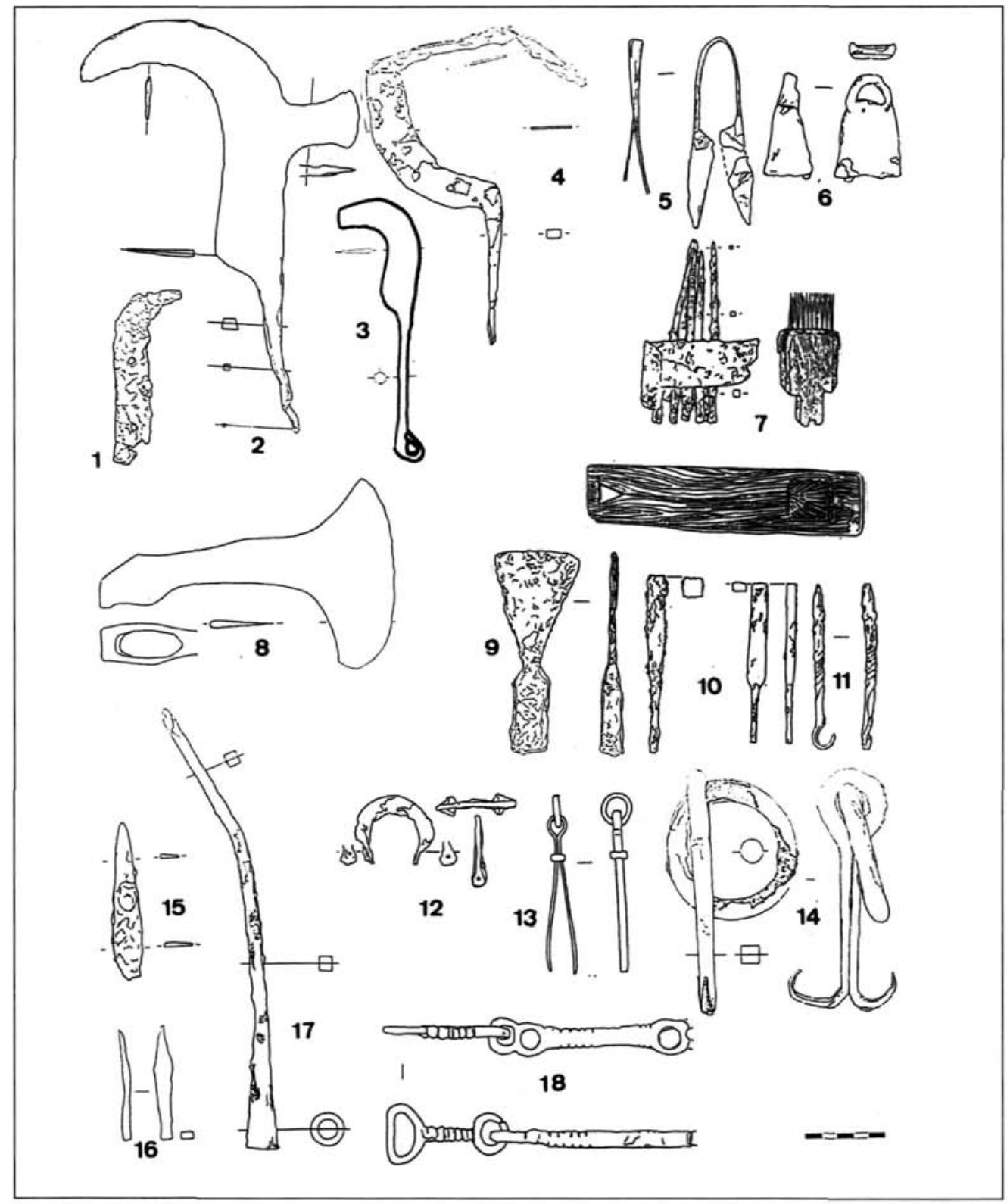

Figura 19. Conjunto de útiles de hierro: Útiles agrícolas: corquetes $\left(n^{\circ} 1\right.$ y 3), podadera $\left(n^{\circ} 2\right)$, hoz $\left(n^{\circ} 4\right)$. Útiles ganaderos: tijeras $\left(n^{\circ} 5\right)$, cencerro $\left(n^{\circ} 6\right)$. Utiles textiles: cardadora de lino $\left(n^{\circ} 7\right)$. Útiles polivalentes: hacha con ojo $\left(n^{\circ} 8\right)$. Útiles de carpinteria: cortafrios $\left(n^{\circ} 9\right)$, escoplo, formón o cincel $\left(n^{\circ} 10\right)$, barrena helicoidal $\left(n^{\circ} 11\right)$. Asa $\left(n^{\circ} 12\right)$. Pinzas $\left(n^{\circ} 13\right)$. Gancho $\left(n^{\circ} 14\right)$. Hoja de cuchillo $\left(n^{\circ} 15\right)$. Útiles de armamento: punta de flecha o jabalina $\left(n^{\circ} 16\right)$, punta de lanza tipo regatón $\left(n^{\circ} 17\right)$. Bocado de caballo $\left(n^{\circ} 18\right)$. 
posición vertical mediante una placa metálica. Dado el grosor de las varillas las hemos identificado como parte de una cardadora de lino (de ser más gruesas se corresponderían con una cardadora de lana). La reconstrucción del útil y su posterior identificación ha sido posible gracias a la comparación etnográfica que nos proporcionó el Museo de Artes y Tradiciones Populares de Madrid así como a la información obtenida de Carreras Candi (1931). En algunos yacimientos arqueológicos (La Cocosa o la villa de Monroy) se constata la existencia de cardadoras pero siempre atribuibles al trabajo de la lana y no del lino.

Un conjunto de útiles destacable es el que posee una funcionalidad variable. La gran diversidad tipológica que muestran nos hace pensar que este tipo de útiles no debían estar demasiado homogeneizados (es posible que cada uno respondiese a unas necesidades específicas). La picoleta presenta dos filos en distinto plano de corte (uno horizontal y el otro vertical), por lo que pudo funcionar como pico y como hacha. Según los paralelos etnográficos manejados, podría tratarse de una hachuela para la poda del olivo. Las dos hachas con ojo (fig. 19.8), de tipología distinta, aunque ambas tengan un filo vertical curvado.

Los Útiles de carpintería que se han encontrado en El Saucedo abarcan desde azuelas de carpintero hasta barrenas (fig. 19.11), pasando por espátulas, escoplos (fig. 16.10), cinceles, cortafríos (fig. 19.9), formones, punzones, barrenas, limas, cepillos de carpintero o garlopas, compases y taladros.

Por último, el armamento identificado corresponde a puntas de lanza de tipo regatón con una función militar (fig. 19.17) y puntas de flecha o jabalina tanto para uso militar como venatorio (fig. 19.16).

\section{Clasificación morfologica}

Dentro de esta clasificación, destaca un bocado de caballo (fig. 19.18), que constituye la única pieza del atalaje de un caballo aparecida en $E l$ Saucedo. Se trata de un freno del que se conserva el elemento central y uno de los laterales. Posee unas características morfológicas particulares y no se corresponde exactamente con ninguno de los publicados. No obstante, se acerca a los modelos que Caballero (1974) incluye en su tipo III de Fuentespreadas.

Otro tipo de instrumentos aparecido son los ganchos (fig. 19.14), algunos de los cuales pueden identificarse como elementos de sujeción para colgar o como elementos de balanzas, mientras que otros pueden vincularse más con actividades de levantamiento de materiales pesados (de construcción probablemente). También pudieron utilizarse para la suspensión de alimentos, recipientes de cocina, textiles, o aperos.

Los cucbillos (fig. 19.15) constituyen un conjunto notable dentro de los hallazgos, no sólo por su número sino también por su tipología diversa. La funcionalidad de todos ellos es variada, aunque principalmente se emplearían para la cocina.

Asas (fig. 19.12), arandelas, eslabones de cadena, pinzas (fig. 19.13), elementos de vestuario, útiles de mobiliario o simples mangos completarían el conjunto de útiles constatados en El Saucedo. 
El estudio de todos ellos (Aguado y Jiménez, 1999) ha servido para comprobar que todas las tipologías documentadas en nuestro yacimiento tienen claros precedentes prerromanos (tesis que defiende Plá Ballester, 1969) y que a la vez son características tanto de Época Bajoimperial como visigoda, perdurando sin grandes modificaciones hasta la Edad Media. La datación de los útiles comprende entre el s.IV y el s.VII d.C. Tan sólo dos instrumentos corresponden a época altoimperial, lo que resulta ser un porcentaje mínimo. El estudio microespacial nos muestra un alto grado de dispersión y mezcla de los instrumentos. No obstante, se observan dos concentraciones significativas de útiles; una en la zona fabril y otra en el "basurero", localizado en la parte posterior de la cabecera de la Basílica.

El trabajo desarrollado hasta el momento ha permitido comprobar que El Saucedo encaja en los patrones establecidos por la investigación para los centros de producción rural de época tardoimperial: residencia del dueño de la propiedad, desarrollo de estrategias económicas autárquicas, situación de inseguridad pero continuidad de los modos de producción... Y en concreto, ha sido posible inferir la existencia de determinadas actividades económicas: actividades agrícolas (de producción para el consumo); trabajo ganadero, en el que el ganado ovicaprino debió ocupar un lugar destacado (existencia de cabañas lanares), mientras el bovino cumpliría las funciones de tiro para el arado así como las de suministrar productos lácteos, cuero...; actividad textil, característica de la vida doméstica de las casas rurales romanas; trabajos forestales y de carpintería, orientados a la necesidades domésticas y actividades contables, de cara a tener un control administrativo de la producción.

Junto a estas actividades hay que mencionar otras como la defensiva y la venatoria, que serían igualmente características del modo de vida de la aristocracia en una propiedad rural. No obstante, todas estas actividades no constituyen el total de las que se pudieron desarrollar, por lo cual, aún no se pueden extraer conclusiones acerca de estrategias globales de producción.

\section{Los HALAZGos NUMISMÁtICOS}

Fueron estudiados en dos artículos. El primero de ellos se presentó en el II Congreso de Arqueología Peninsular, celebrado en Zamora en 1996 y publicado en 1999 y el segundo fue publicado en el Boletín de la Asociación Española de Amigos de la Arqueología. Las monedas de ambos estudios suman un total de 47 (30 de las cuales se encuentran depositadas en el Museo de Santa Cruz de Toledo) y proceden de las colecciones cedidas al Museo por D. Martín Aguado y D. Eugenio Manzano (15), reunidas a través de prospecciones, excavaciones y diversas visitas (circunstancias que nos privan de obtener datos relativos a su estratigrafía y a su situación en el yacimiento) así como de las excavaciones arqueológicas realizadas por el Departamento de Prehistoria y Arqueología de la UAM en 1982, 1986, 1995 y 1996.

El estudio de las monedas recuperadas puede aportar interesantes datos para el conocimiento de lo que fue una importante explotación agrícola de la época y, por exten- 
sión, de la circulación monetaria de la zona. La moneda más antigua de las catalogadas fue emitida en el taller de Roma a nombre de Lucilla. Se puede fechar en un momento posterior al 161. Si bien contamos con una primera fase de ocupación altoimperial no podemos decir que ésta moneda la feche. No obstante, debemos tener en cuenta que, tal y como se ha constatado en tesorillos y en otro tipo de hallazgos, las monedas de época de los Antoninos seguirán en circulación hasta bien entrado el siglo III, por lo que la fecha de su pérdida se podría retrasar en casi una centuria. Este numisma de Lucilla, por tanto, podría muy bien englobarse en una misma etapa con las piezas recuperadas de Galieno o Claudio II.

Del emperador Galieno poseemos dos antoninianos, uno acunado en Roma (entre el 260-268) y otro en Nicomedia. De Claudio II tenemos un antoniniano acuñado en la ceca de Roma entre el 268-269 (Castelo et alii, 1999, 272). Las monedas del emperador Constantino cubrieron la mayoría de las necesidades del circulante entre el 313 y 337 . En las monedas documentadas en El Saucedo se ha podido constatar el hecho de que en los primeros años del siglo IV llegaron a Hispania monedas procedentes en su mayoría de cecas occidentales, predominantemente galas. En nuestro yacimiento nos encontramos con cuatro ejemplares procedentes de Tréveris, Arelate y Amiens, frente a los dos ejemplares de la ceca de Roma. También se han constatado dos piezas emitidas en una de las cecas Balcánico-Danubianas (Siscia); y en Asia Menor (Heraclea y Nicomedia).

El siglo IV se encuentra cubierto en su totalidad en El Saucedo con hallazgos de monedas emitidas por Constantino Cloro; Constantino I, Magnencio, Decencio, Constancio II, Juliano II; Valentiniano II, Magno Máximo, Teodosio y Honorio.

Posteriormente a estas piezas, encontramos un paréntesis cronológico hasta bien entrada la época visigoda, que será el último gran periodo monetal documentado en la villa representado por un triens de Recaredo y otro de Witiza (Castelo et alii, 1999, 274). La pieza de oro de Recaredo emitida en Toledo y con leyenda TOLETO PIUS (Castelo et alii, 1999, 275). La pieza de Witiza es quizás la más interesante del yacimiento porque nos fecha el último periodo de ocupación del yacimiento. Procede de la ceca de Mérida. La moneda se fecha entre el 702 y el 710 .

\section{ACTIVIDAD LÚDICA}

\section{Fichas de Juego}

En 1997 el equipo de excavaciones de El Saucedo llevó a cabo un estudio sobre las numerosas fichas de juego, mayoritariamente en cerámica, y otros elementos, ocellati (Aguado et alii, e.p. c).

Las mayoría de las piezas discoidales analizadas proceden del área termal y del basurero, fechados.en el s. IV. En la campana de 2000 se han hallado numerosos ejemplares en la ampliación de la zona termal, lo que ratifica su vinculación con el tiempo de ocio de los antiguos romanos. 
El conjunto de los materiales estudiados se compone de 58 piezas discoidales de céramica (terra sigillata, cerámica común y pintada), a excepción de un canto rodado, a las que hemos de añadir dos canicas, en terracota y piedra, respectivamente.

Para lograr la forma discoidal, las piezas fueron talladas mediante un percutor (piedra o martillo) y posteriormente los cantos fueron pulidos. Su diámetro se halla comprendido entre $2,2 \mathrm{~cm}$. y $5,5 \mathrm{~cm}$. (fig. 20).

El segundo elemento diagnóstico que nos permite diferenciar las fichas, además del tamaño es el del color. Existían en la antigüedad grupos de juegos a los que correspondían fichas de tamaño precisos, como el ludus latrunculorum, al que solía jugarse con piezas pequeñas, posiblemente del tipo 1 . Respecto al color, se distinguen dos grupos: fichas claras o rojas, el grupo más abundante, y oscuras o negras.

En este estudio se han incluido dos piezas que por sus características han sido identificadas como ocellati o canicas (fig. 20). El empleo de bolas y canicas para juegos domésticos en Roma está atestiguado por las fuentes y los restos arqueológicos, en forma de tableros con oquedades y objetos esféricos.

Por otro lado, son varias las fichas que presentan marcas incisas en su superficie, probablemente para distinguir alguna ficha determinada o las fichas de uno de los dos jugadores En una de ellas se observa una letra "A" grabada. En una segunda destaca una decoración de círculos dentados, procedentes del fragmento de cerámica sigillata originaria, así como una pequeña perforación de forma hemiesférica en el centro de cada una de sus caras.

Los juegos a los que estas fichas pudieron haber sido destinados son el duodecim scripta, el alquerque de nueve o molino, las tres en raya, y las canicas, principalmente. Sin embargo, aún es necesario encontrar tabulae lusoriae, tesserae u otros elementos relacionados con ellos, no conservados, porque estarían fabricados en materiales perecederos, o bien pintados o grabados sobre el pavimento, incluso sobre ladrillos o en la tierra.

\section{AVANCES INTERPRETATIVOS}

Durante la última campaña de excavación en el año 2000 se han priorizado las labores de investigación sobre las estructuras arquitectónicas y las actividades relacionadas con la vida cotidiana durante las fases de ocupación del yacimiento, su conservación y la difusión de los resultados de la investigación.

Las nuevas interpretaciones referidas a las estructuras arquitectónicas conocidas son por el momento hipótesis de trabajo, pero se puede avanzar que el gran complejo termal, al que hemos hecho alusión anteriormente, estaría integrado en una villa de dimensiones mucho mayores a las consideradas en un principio y aún desconocidas. También es probable que las estructuras del denominado "Pabellón" formasen parte de la domus de dicha villa. El complejo termal consistiría entonces en un gran salón distribuidor y apodyterium, decorado con gran lujo (mosaicos, estucos, etc.), una sucesión de frigidarium, tepidarium 


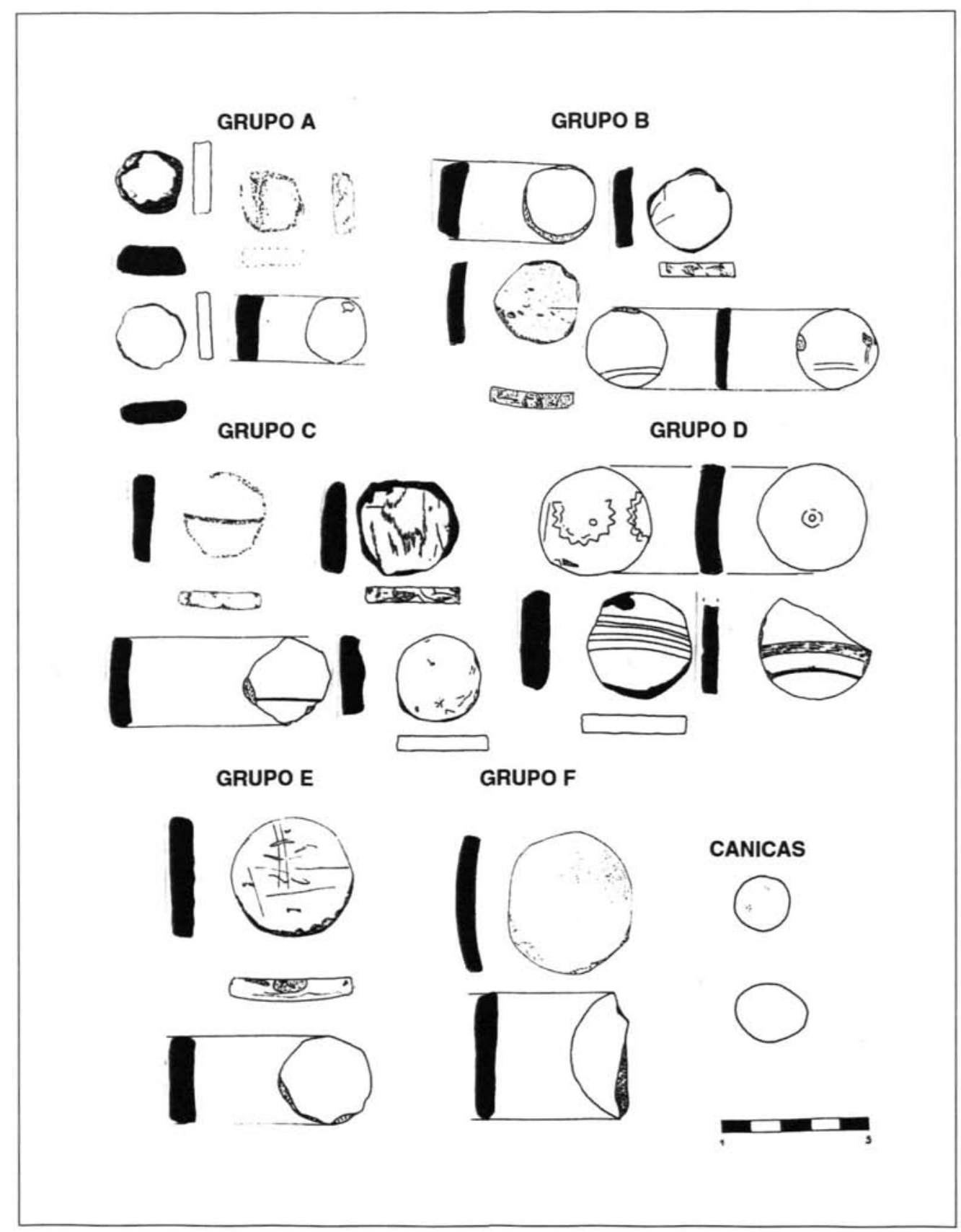

Figura 20. Conjunto de fichas de juego en cerámica agrupadas según su diámetro, y canicas de cerámica y mármol. 
y caldarium y una habitación calefactada de planta octogonal con una exedra, que puede interpretarse como una sudatio. El sistema de calefacción documentado en el yacimiento sería el característico de la Lusitania.

Así pues, mantenemos que en la fase del s. III-IV d. C. El Saucedo se interpretaría como una Villa suburbana de tipo palaciego, con una distribución en planta de tipo "U" o anular, cercana a una ciudad en auge en ese periodo, pero que mantenía el control sobre un amplio territorio fértil de la vega del Tajo. En ella debieron de concentrarse las actividades económicas y sociales propias de este tipo de asentamiento.

En la siguiente fase de ocupación, datada entre los siglos V y VIII, la vida giraría en torno a la Basílica que se levanta en el gran salón absidado de las termas antiguas y al centro de producción y redistribución agropecuaria y artesanal que se establece a su alrededor. La aparición de una Basílica en este preciso lugar estaría en relación con los procesos de cristianización de lugares con cierto valor sacro o religioso en su pasado reciente. Quizá en nuestro caso habría que pensar en un posible culto a las aguas o las ninfas (las fuentes cercanas y las termas podrían avalarlo). Debieron de existir igualmente espacios de vivienda de los trabajadores en una explotación de este tamaño y, por tanto, también de los propietarios (aunque aún no están localizados físicamente).

Este tipo de grandes explotaciones latifundistas centralizaban en la época, no sólo la producción sino a la población rural de los alrededores en torno al culto desarrollado en las basílicas. Pensamos que El Saucedo podría entenderse tanto como una propiedad familiar en la que el "terrateniente" cede un espacio para la ubicación de una pequeña iglesia rural o como una propiedad eclesial o privada de otro tipo gestionada por una comunidad religiosa.

\section{ESTADO DE CONSERVACIÓN}

\section{Estado Actual}

Las estructuras arquitectónicas presentan un alto grado de arrasamiento, por las labores agrícolas desarrolladas en la parcela. En el yacimiento se ha detectado también la degradación de las estructuras, debido a agentes de origen climático (clima continental de oscilaciones extremas) y orgánico. En cuanto a éstas últimas se han producido en las zonas en las que se han detectado fugas de agua de la acequia. Los daños producidos por causa de la humedad se concretan en: proliferación de colonias de hongos y de hierbas sobre muros y pavimentos. Por último, acciones de origen animal han contribuido a la degradación del yacimiento: los hormigueros bajo los pavimentos musivarios y los túneles realizados por roedores. 


\section{Campañas de Restauración y Consolidación}

En la campaña de 1996 los trabajos arqueológicos realizados estuvieron acompañados por trabajos de limpieza, análisis, consolidación y arranque de los pavimentos musivarios documentados en el Área II, por parte de la Escuela Superior de Conservación y Restauración de Bienes Culturales de Madrid.

En 1997 se procedió a realizar trabajos de restauración consolidación y conservación de los mosaicos extraídos en la campaña anterior. Estos trabajos fueron llevados a cabo una vez más por miembros de la Escuela Superior de Conservación y Restauración de Bienes Culturales.

Durante la campaña del año 2000 se han realizado diversas labores de consolidación y conservación en el yacimiento. Han consistido en: consolidación de pinturas murales aparecidas en campanas de excavación anteriores y en los revocos y estucos tanto de la última campaña, como los conservados in situ en las fauces del gran salón; consolidación del opus signinum de la nueva piscina hallada y de la piscina bautismal, y de las nuevas pilae documentadas en el hipocausto de la habitación octogonal; y renovación de los sistemas de protección preventiva en el hipocausto excavado y protegido en la campaña de 1995 hasta que pueda realizarse su restauración definitiva. Finalmente se ha cubierto el yacimiento una vez finalizada la campaña actual.

\section{Prioridades en Conservación}

A tenor de lo dicho anteriormente, las próximas actuaciones a llevar a cabo en el yacimiento serían las siguientes: recrecimiento de muros, para evitar su deterioro; tratamiento de los mosaicos en tres ámbitos: consolidación y restauración de los mosaicos todavía in situ, de los depositados en el Museo de Santa Cruz de Toledo y en proceso de traslado al Museo Ruiz de Luna de Talavera de la Reina, y reintegración de mosaicos, levantados y consolidados en las campañas de los años 96 y 97 , actualmente almacenados en condiciones poco óptimas; y, de modo prioritario el desarrollo de estrategias de conservación preventiva, siendo la principal la eliminación de los riesgos de deterioro que sufre el yacimiento a causa del recorrido actual de la acequia para el riego.

\section{DIFUSIÓN DE LOS RESULTADOS DE LA INVESTIGACIÓN}

Hace tiempo que desde diferentes ámbitos vienen incrementándose los esfuerzos por definir y transmitir el concepto de la dimensión social de la investigación, ya que el conocimiento que una sociedad posee de su pasado, sobre todo si éste responde a los planteamientos teórico-metodológicos más avanzados, configura la imagen que tiene de sí misma, le permite vislumbrar las posibilidades de hacer que en el futuro (pero también en el presente más inmediato) sea más tolerante, solidaria y libre. 
La mayoría de los profesionales de la Arqueología somos ya conscientes de que la actividad arqueológica va más allá de la mera excavación y que el trabajo sólo puede darse por terminado cuando los restos encontrados se disponen para su rentabilización sociocultural. Esta actitud no deviene sólo del convencimiento personal respecto de una argumentación teórica, sino también del conocimiento de la normativa vigente en las diferentes administraciones (Estatal, autonómica, etc.) sobre la labor del arqueólogo: Según el preámbulo de la LPHE de 1985 "los bienes del Patrimonio lo son debido exclusivamente a la acción social que cumplen". Por otro lado, la Ley del Patrimonio Histórico de Castilla-la Mancha establece como una de sus pretensiones la de "(...) conservar y extender la pluralidad de una riqueza cultural, cuyo conocimiento y disfrute estético permita transmitir a las futuras generaciones un patrimonio labrado sobre la tolerancia y abierto a la solidaridad creativa". Estos dos párrafos expresan con rotundidad la finalidad social del Patrimonio Histórico, en el que se encuadra el Patrimonio Arqueológico.

En consecuencia con todo lo dicho, se exponen a continuación los objetivos para la difusión a todo tipo de público de la investigación sobre el yacimiento de El Saucedo y las estrategias diseñadas para alcanzarlos y que el equipo de investigación se ha marcado hasta el presente:

\section{Objetivos:}

1. La transmisión de resultados a la comunidad científica a través de diferentes tipos de publicaciones, dadas a conocer en Congresos de Arqueología o específicos, en revistas especializadas, etc.

2. La enseñanza de la Historia a través del yacimiento. Con este objetivo de corte didáctico se ha tratado de conseguir la transmisión de conocimientos sobre la propia historia del yacimiento, así como sobre la historia local al público no especializado, empezando por la población cercana, los niños y adolescentes que lo han visitado, el turismo ocasional, etc.

3. El fomento de valores de respeto al Patrimonio y de comprensión del trabajo de los arqueólogos. La concienciación y sensibilización de la población cercana respecto del valor intrínseco del patrimonio histórico-artístico es el mejor garante de su conservación futura. Así también, su acercamiento al mundo de la Arqueología científica es la mejor vía para incrementar la consideración social de nuestro colectivo, lo cual redunda siempre en una mayor atención por parte de los agentes encargados de la protección legal y la financiación de la investigación y puesta en valor de los yacimientos y por tanto, en una mejora de las perspectivas de futuro del propio Patrimonio.

Estos objetivos se han concretado hasta ahora atendiendo a tres niveles ordenados aquí con un criterio de menor a mayor globalidad:

a. El conocimiento del yacimiento: a este nivel, la pretensión del equipo de investigación de El Saucedo ha sido y es la de dar a conocer su espacio y su tiempo, es decir, facilitar en la medida de lo posible su visita, transmitir su existencia y explicar sus características arquitectónicas, desarrollo cronológico, restos materiales, así como las técnicas del trabajo arqueológico. 
b. La interpretación arqueológica: en este campo se incluye la transmisión de los frutos de la investigación sobre el yacimiento, orientada tanto a especialistas como a público en general.

c. El proceso bistórico de la región: por último, la difusión de conocimientos se centra en dar a conocer el marco histórico cultural en el que se desarrolló la microhistoria del yacimiento, explicando el proceso de cambio que afectó a la rivera del Tajo durante el período comprendido entre el siglo I. d.C. y el final de la Tardoantigüedad.

\section{Estrategias:}

Las estrategias que han permitido el cumplimiento total o parcial de las pretensiones arriba indicadas han sido diversas en los últimos años. Algunas tuvieron un desarrollo puntual y otras poseen un carácter más permanente. En concreto, para la difusión del trabajo realizado en El Saucedo se han puesto en marcha:

1. Visitas al yacimiento: A lo largo de las dos últimas campanas se prepararon Jornadas de Puertas Abiertas, en las que durante una serie de tardes destinadas a tal fin se ofrecían explicaciones (visitas guiadas) al yacimiento por parte de los miembros del equipo. También se han concertado visitas de grupos de estudiantes y especialistas, como las efectuadas por los alumnos del Curso de Doctorado Arquitectura y Estructuras arqueológicas: Conservación y restauración del Patrimonio del profesor D. J. Barrio de la U.A.M., los de la Escuela Taller "Casco Histórico" de Talavera de la Reina y los del Curso de "Auxiliar de Arqueología" que se impartió este otoño en esta misma ciudad bajo dirección de D. Alberto Moraleda. También visitaron el yacimiento los miembros del Instituto Arqueológico Alemán de Madrid. Así mismo, con motivo de la celebración en Talavera de la Reina las "I Jornadas de Arqueología romana en Talavera", El Saucedo se incluyó dentro del programa de visitas organizadas para los congresistas.

2. Exposiciones: Desde finales de 1999 hasta hoy se han expuesto dos montajes museográficos relativos al yacimiento. El primero, titulado El Saucedo, un enclave histórico desde el período romano al islámico" se expuso en la Casa de la Cultura del Municipio de Talavera la Nueva y el segundo, bajo el título de "Talavera Romana. El ámbito rural romano en Talavera: La Villa de El Saucedo", se encuentra actualmente abierto al público en el Museo Ruíz de Luna de Talavera de la Reina , habiéndose iniciado su montaje con motivo de las citadas "I Jornadas de Arqueología Romana en Talavera" celebradas en Noviembre de 2000 .

3. Actividades didácticas: Se han elaborado materiales didácticos para el trabajo coordinado con docentes de primaria y secundaria, con objeto de que posteriormente sus alumnos realicen una visita al yacimiento en la que se proporcione una explicación adaptada y se realicen actividades didácticas. Contamos con la experiencia de una visita de alumnos de Secundaria y otra del Colegio de Talavera la Nueva "San Isidro" con sus cinco cursos de Primaria.

Pese a todo, existen, hoy por hoy, serias limitaciones en el desarrollo de las potencialidades del yacimiento en materia de rentabilización socio-cultural. No está acondicionado para las visitas y por tanto no está abierto al público más que en los momentos en 
que el equipo de investigación trabaja en él. El Saucedo aparece incluido en una ruta de Turismo Cultural promovida por el Exmo. Ayuntamiento de Talavera de la Reina y financiada por un programa Leader II y la Junta de Comunidades de Castilla la Mancha, entre otros, pero su nivel de incidencia es mínimo debido a la circunstancia antes mencionada. Por otro lado, tampoco existe aún un Proyecto Didáctico que abarque todas las posibilidades de transmisión de conocimientos que podría proporcionar el yacimiento.

Por estas y otras razones, el proyecto de futuro de $\mathrm{El} \mathrm{Saucedo}$ pasa necesariamente por la estructuración de un Plan de Gestión y Difusión que permita dotar de todo su sentido social a un lugar con enormes posibilidades y de alto interés científico y educativo.

\section{PERSPECTIVAS DE FUTURO}

El Plan de Gestión y Difusión contempla, pues se encuentra ya esbozado, la organización coordinada de todas las tareas a desarrollar en cada uno de los niveles del trabajo, así como en cada fase del mismo. Así pues, siguiendo las recomendaciones que diferentes autores, como Ruiz et alii (1999) y $\mathrm{M}^{2}$ Ángeles Querol (1999), entre otros, han aportado en Congresos de Arqueología, Encuentros sobre patrimonio o Cursos sobre la "puesta en valor" de yacimientos arqueológicos, este Plan consta de un área de Investigación, otra de Conservación y otra de Difusión.

Defendimos anteriormente que el trabajo del arqueólogo sólo puede darse por terminado cuando los restos encontrados se disponen para su rentabilización socio-cultural y que por ello, es imprescindible incrementar el trabajo de sensibilización y acercamiento de la Arqueología en general y el yacimiento en particular al público. Ambos objetivos se pueden alcanzar hoy día a través de una vía que está recibiendo más apoyos cada vez por parte de los diferentes agentes implicados en la gestión del patrimonio: el turismo cultural.

La apertura al público de los yacimientos de forma continuada y con todos los servicios que implica se está mostrando como un medio de actuación que ofrece garantías para su conservación y muy útil para involucrar a los ciudadanos en la misma, así como para fomentar el respeto a lo que representan. Igualmente, es una fórmula de desarrollo económico muy apta para regiones desfavorecidas o en crisis que requieren de revulsivos como éste, capaces de crear puestos de trabajo y renovar el tejido del sector servicios, aprovechando los recursos patrimoniales del entorno y por tanto, sin agredir al medio ambiente.

El concepto de la rentabilidad social de una intervención arqueológica está aún abriéndose camino en nuestro país. La mayoría de los arqueólogos sabemos que el acercamiento de los ciudadanos a los restos del pasado provoca respuestas emocionales e intelectuales que lo enriquecen y revierten después positivamente en el propio patrimonio. Por todo ello, la preparación de El Saucedo para su apertura al público se presenta como un reto emocionante y necesario. Pues bien, para que la incidencia social de un yacimiento sea elevada deben darse varias condiciones: que esté dotado de una infraestructura adecuada para la visita y que la información que se transmita esté adaptada a los diferentes 
niveles de comprensión de los visitantes. También requiere de una publicidad adecuada y ser capaz de ofertar una visita al tiempo lúdica y formativa, en conexión con la realidad cotidiana pero también con la enseñanza. Autores como $\mathrm{M}^{\mathrm{a}}$ Ángeles Querol (1999) instan, en este sentido, a que en los equipos de investigación se integren expertos en didáctica que satisfagan estas condiciones.

\section{Plan Director}

El esbozo del Plan Director para El Saucedo propone el desarrollo del trabajo del equipo en tres áreas (Investigación, conservación y difusión), como comentamos anteriormente y se puede observar en los cuadros esquemáticos adjuntos (figs. 21, 22 y 23), además de incluir un plan de financiación (un modelo de presupuesto para el mantenimiento del yacimiento):

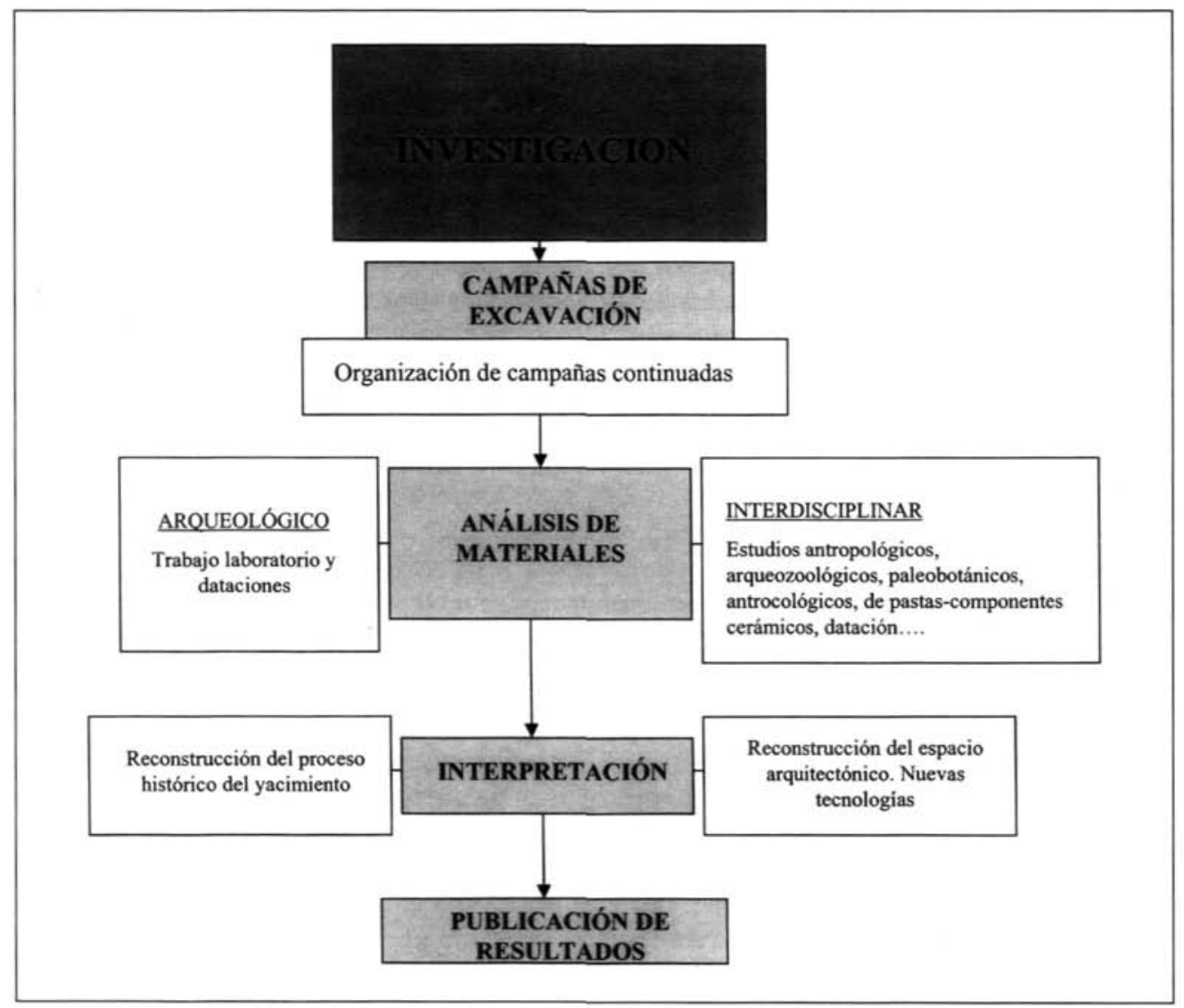

Figura 21. Cuadros-resumen sobre las actuaciones en investigación programadas en El Saucedo. 


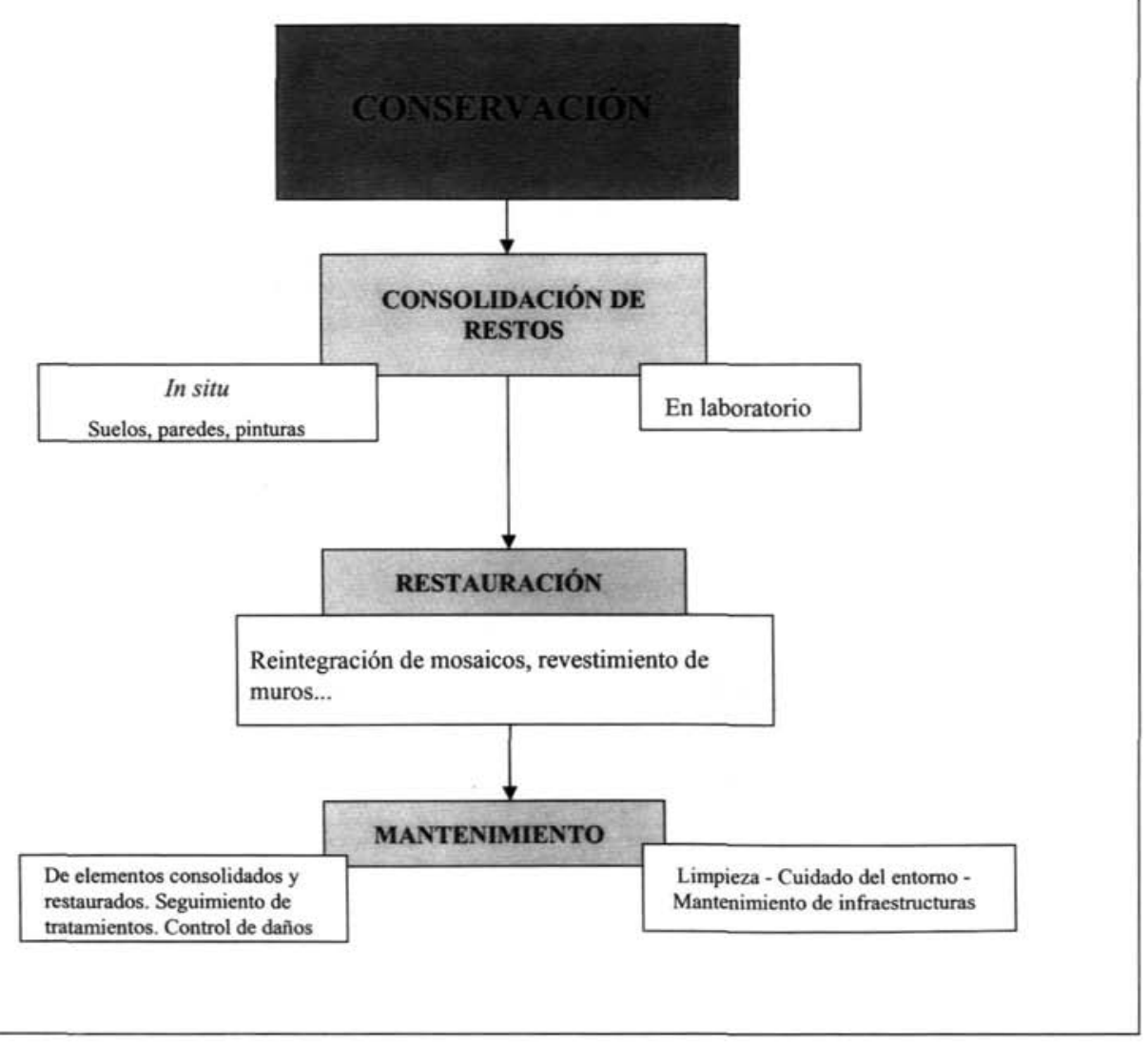

Figura 22. Cuadros-resumen sobre las actuaciones en conservación programadas en El Saucedo.

En los cuadros esquemáticos que se adjuntan sólo faltaría por especificar el Proyecto Didáctico del yacimiento. La definición de actuaciones de mayor calado que la mera creación de materiales para la explicación adaptada del sitio encuentra referentes hoy día en diversos yacimientos arqueológicos que cuentan con Aulas Didácticas, espacios para talleres y el desarrollo de actividades con niños, o bien en los programas de colaboración permanente entre arqueólogos y docentes, incluso de diferentes centros educativos europeos. Así, conocemos, entre otros, los casos de las Aulas de Atapuerca (Burgos) o de las Minas de Can Tintoré en Gavá; las experiencias en formación de adolescentes en la práctica arqueológica (aprendizaje del método científico y respeto al patrimonio) llevadas a cabo en Plaza de Moros (Toledo) (Urbina y otros, 2001); el Proyecto educativo de cooperación europea "Los Primeros agricultores", llevado a cabo por un I.E.S. catalán y otros dos centros, de la Bretaña Francesa e Inglaterra, durante los años lectivos 1997/98 y 99/2000 (Bardavio y 


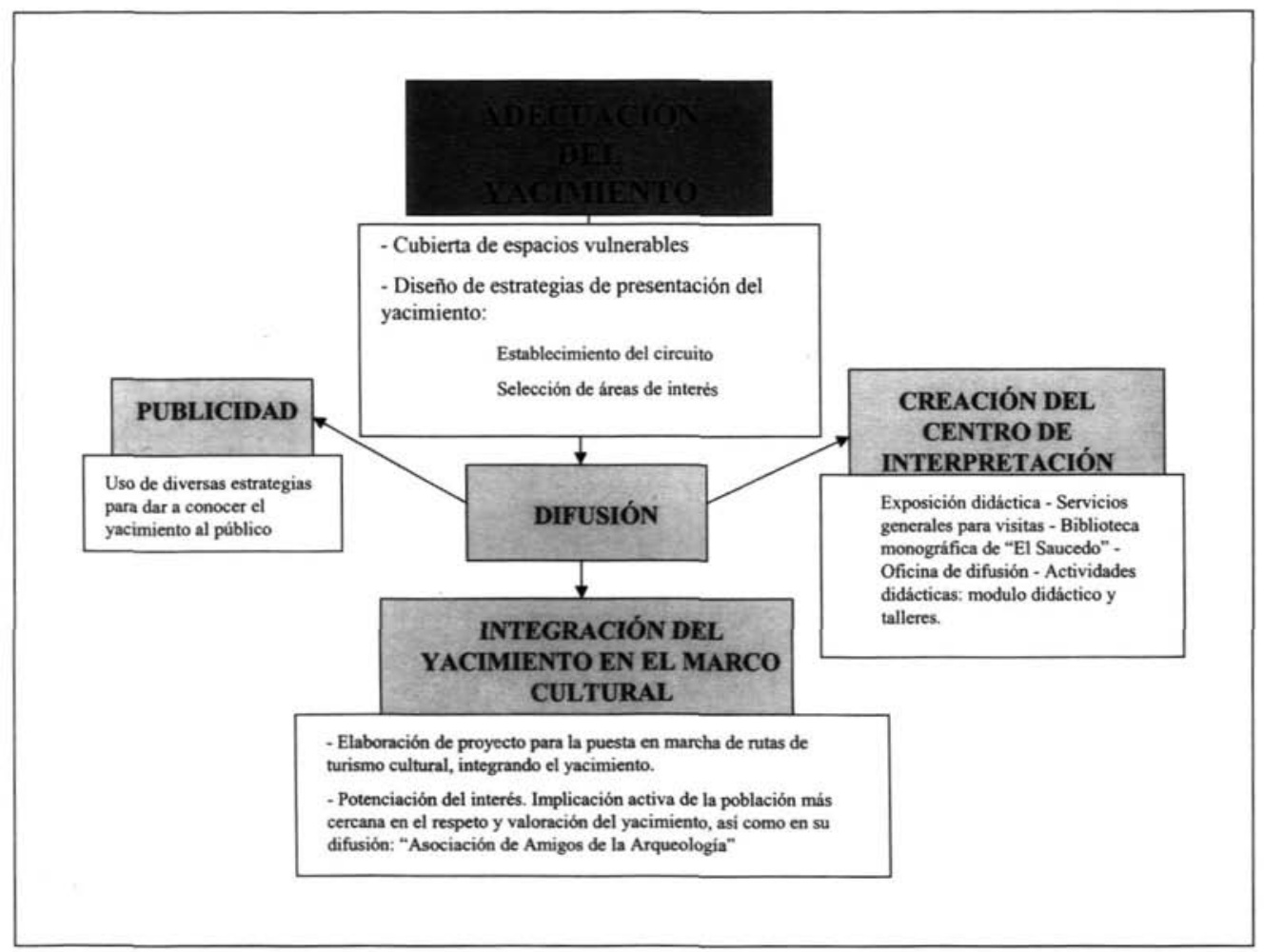

Figura 22. Cuadros-resumen sobre las actuaciones en conservación programadas en El Saucedo.

Gatell, 2000). Todos ellos y otros muchos de similar carácter se han saldado con valoraciones positivas y ofrecen modelos a tener en cuenta en lo referente a la configuración de un proyecto de difusión orientado a los más jóvenes que sea consistente.

Para finalizar, sólo queremos redundar en la importancia del proyecto de rentabilización social de un sitio arqueológico con múltiples posibilidades, que ya recibe la valoración y el reconocimiento por parte de la población inmediata, así como de la comunidad científica y la administración de la Junta de Castilla la Mancha, y que por todo ello, podría deportar muchos frutos en años venideros. 


\section{BIBLIOGRAFIA}

AA.VV. (1998): Complutum. Roma en el interior de la Península Ibérica. Catálogo de la Exposición. Alcalá de Henares. 18 de mayo a 26 de julio 1998, 1a ed. (mayo 1998), Alcalá de Henares.

AGUADO, M.; CASTELO, R.; JIMÉNEZ, O.; LÓPEZ, A.; SIERRA, C.; SIERRA, C.; TALÉNS, C. y TORRECILLA, A., (e.p. a): "El Saucedo. Una propuesta de gestión del Patrimonio en el ámbito rural", I Jornadas de Arqueología Romana de Talavera "Hércules 2000", Talavera de la Reina (Toledo), 23-25 de noviembre de 2000.

AGUADO M., JIMÉNEZ O., LÓPEZ A., PANIZO I., TORRECILLA A., (e.p. b): “Juegos domésticos en la Hispania Romana. Las fichas de juego de la villa de El Saucedo (Talavera la Nueva, Toledo)", Actas del II Encuentro "Hispania en la Antigüedad Tardía: Ocio y Espectáculos". Alcalá de Henares, 15-17 de octubre, 1997.

AGUADO M., JIMÉNEZ O., LÓPEZ, A., PANIZO, I. y TALENS, C., (e.p. c): "Los materiales de hueso trabajado de la villa de El Saucedo (Talavera la Nueva, Toledo)" $3^{\circ}$ Congreso de Arqueología Peninsular (Vila Real, 21-27 setembro 1999).

AGUADO, M., JIMÉNEZ O., RECIO R. (1999): "Las actividades económicas en la villa de El Saucedo. Estudio de los materiales de hierro", XXIV Congreso Nacional de Arqueología (Cartagena, 1997), pp. 417-433, Cartagena.

ÁLVÁREZ MARTínEZ, J.M. (1976). "La villa romana de el Hinojal en la Dehesa de las Tiendas (Mérida)", N.A.H., Arq, 4 , pp. 433-488. Madrid.

ARRIBAS DOMÍNGUEZ, R. (1999): "Los balnea privados en el ámbito rural lusitano: observaciones preliminares sobre los modelos arquitectónicos", en Économie et territoire en Lusitanie Romaine, J.G. Gorges et F.G. Rodríguez Martín (eds.). Colletion de la Casa de Velázquez n ${ }^{\circ}$ 65, pp. 427-451. Madrid.

ARRIBAS DOMÍNGUEZ, R., (1999): "Hypocausta en la Lusitania romana. El Hypocausto de la villa de El Saucedo (Talavera la Nueva, Toledo)”, XXIV Congreso Nacional de Arqueología, pp. 383-395. Cartagena.

ARRIBAS, R. y TORRECILLA, A. (2000): "Las Termas de la villa de "El Saucedo" (Talavera la Nueva, Toledo)", Coloquio Internacional Termas Romanas en el Occidente del Imperio, Gijón (1-3 diciembre de 1999), pp. 327-334. Gijón.

ARRIBAS, R.; CASTELO, R.; BENDALA, M., (1999): "La villa de El Saucedo (Talavera la Nueva, Toledo): Aproximación al estudio de los materiales cerámicos", Boletín de la Sociedad Española de Cerámica y Vidrio, 38 (4), pp. 307-321. Madrid.

BARDAVIO, A. y GATELL, C., (2000): "Els primers pagesos. Un projecte educatiu en el marc de la Unió Europea”, en González, P. (Edit), Actas del III Seminari de Arqueologia $i$ Ensenyament, Barcelona, 2000, Treballs D'Arqueologia, $n^{\circ} 6$, pp. 13-41.

BENDALA, M.; CASTELO, R. y ARRIBAS, R. (1998): "La villa romana de El Saucedo (Talavera la Nueva, Toledo)", Madrider Mitteilungen, 39. pp. 297-310. Mainz.

BOUET, A. (2000): "Les modèles thermaux et leur diffusion en Gaula", Termas romanas en el Occidente del Imperio. Coloquio Internacional, pp. 35-46. Gijón. 
CABALLERO ZOREDA, L., (1974): La Necrópolis tardorromana de Fuentespreadas (Zamora). Un asentamiento en el valle del Duero, Exc. Arq. Esp n80, Madrid.

CANTO A.Ma (2001): "El paisaje del Teónimo: Iscallis Talabrigensis y la aspirina”, Actas del IX Congreso Internacional de lenguas y culturas paleobispánicas: Religión, lengua y cultura, Salamanca, 11-15 de mayo 1999, 107-127. Universidad de Salamanca.

CARRERAS CANDI, F. (1931-33): “Aperos de labranza”, Folklore y Costumbres de España, pp. 289-376.

CASTELO R., ARRIBAS R., LÓPEZ A., PANIZO I. y TORRECILlA A. (1997): "La villa romana de El Saucedo (Talavera la Nueva, Toledo): construcciones termales y recientes hallazgos monetarios", Boletín de la Asociación Española de Amigos de la Arqueología, 37, pp. 63-98, Madrid.

CASTELO R; GÓMEZ, P; TORRECILLA, A; ARRIBAS, R; PANIZO, Y. (1995): “Apliques de asa de situlae con decoración antropomorfa procedentes de la villa romana de El Saucedo (Talavera la Nueva, Toledo)" CUPAUAM $n^{\circ} 22$, pp.125-164, Madrid.

CASTelO, R., LÓPEZ, A., TORRECILlA, A., y PANIZO, I., (2000): "La villa de El Saucedo y su conversión en basílica de culto cristiano. Algunas notas sobre el mosaico de iconografía pagana ubicado en su cabecera", V Reunió d'Arqueología Cristiana Hispánica, Barcelona (Cartagena, 1998).

CASTELO, R., RODRÍGUEZ, I., PANIZO, I. y LÓPEZ, A. (1999): “Aproximación a la cronología y desarrollo de la villa de El Saucedo (Talavera la Nueva, Toledo) a través de las estructuras arquitectónicas y hallazgos numismáticos", II Congreso de Arqueología Peninsular. Arqueología romana y medieval, T. IV, 267-281, Madrid (Zamora, 1996).

CORNIDE Y SAAVEDRA, J. (1796): "Continuación de la memoria de D. Ignacio Hermosilla sobre las ruinas de Talavera la Vieja", Memorias de la Real Academia de la Historia, I, 363-408.

CORREIA, V.H. y REIS, M.P. (2000): “As termas de Conimbriga: tipologías arquitectónicas e integraçao urbana”, Termas romanas en el Occidente del Imperio. Coloquio Internacional, 271280. Gijón.

DURÁN CABELLO, R. (1991): "Las técnicas constructivas de la llamada Casa-Basílica de Mérida", La casa urbana bispanorromana, Zaragoza, 1987, 359ss.

FERNÁNDEZ GÓMEZ (1987): "La basílica y necrópolis paleocristiana de Gerena (Sevilla), $N A H$, 29. Madrid.

FERNÁNDEZ CASTRO, Ma.C. (1982 ): Villas romanas en España. Madrid

FERNÁNDEZ OCHOA, C. et alii (1997): "Proyecto Veranes. Arqueología e historia en torno a la vía de la Plata en el Concejo de Gijón (Asturias)", CuPAUAM, 24, 253-270, Madrid.

FERNÁNDEZ OCHOA, C. et alii (2000): "Grandes conjuntos termales públicos en Hispania", Termas romanas en el Occidente del Imperio. Coloquio Internacional, 59-72. Gijón.

FINCKER, M. (1986): "Les briques claveaux: Un matériau de construction spécifique des Thermes Romains", Aquitania, 4, 143-150. Bordeaux.

FITA, F. (1882): "Inscripciones romanas de Talavera", Boletín Real Academia de la Historia, II, 248-302. Madrid.

FLORIANO, A. (1944): "Excavaciones en Mérida", AEspA, 17, 172ss. Madrid. 
FUENTES DOMINGUEZ, A., (1989): La necrópolis Tardorromana de Albalate de las Nogueras (Cuenca) y el problema de las denominadas "necrópolis del Duero", Excma. Diputac. Provincial, Cuenca.

GARCÍA ENTERO, V. y ARRIBAS DOMÍNGUEZ, R. (2000): "Los balnea de las villae y su proceso de monumentalización", Termas romanas en el Occidente del Imperio. Coloquio Internacional, 83-96. Gijón.

GARCíA y BELLIDO, A. (1952): "La Astigi (Écija) romana," AEspA, XXV, 392-399. Madrid.

GONZÁLEZ CASARRUBIOS, C. (1985): "Trabajo de los metales”, El arte popular en Ávila, pp. 47102. Ávila.

GONZÁlEz CASARRUBIOS, C. (1996): La artesanía del Hierro en la Mancha Toledana. Diputación Provincial de Toledo.

HAUSCHILD, Th. Y ARBEITER, A. (1993): La villa romana de Centcelles. Barcelona.

JIMÉNEZ, O.; LÓPEZ, A.; SIERRA, C.; TORRECILLA, A. AGUADO, M..; CASTELO, R (e.p.): "Últimos hallazgos en el yacimiento de El Saucedo (Talavera la Nueva, Toledo)", I Jornadas de Arqueología Romana de Talavera "Hércules 2000", Talavera de la Reina, 23-25 de noviembre de 2000.

MARTÍN AGUADO, M. (1965): "Para la Historia de Talavera: Saucedo", Separata de Provincia, 49. Toledo.

MINGOTE CALDERÓN, J.L. (1990): Catálogo de aperos agrícolas del Museo del Pueblo Español.

ORTEGO y FRÍAS, T. (1961): "La villa romana de Santervás del Burgo (Soria)", VI Congreso Nacional de Arqueología (Oviedo, 1959), pp. 219-228,. Zaragoza.

ORTEGO y FRÍAS, T. (1969): "Memoria de las excavaciones en la villa romana de Los Quintanares, en el término de Rioseco (Soria)", NAH, X-XII (1966-1968), pp. 235-242, Madrid.

PACHECO JIMÉNEZ, C. y MORALEDA OLIVARES, A. (1997): "Aportación al estudio de estructuras termales en Talavera de la Reina (Toledo)", Termalismo Antiguo (I Congreso Peninsular. Actas), M. J. Peréx (ed.), UNED, Casa de Velázquez, Madrid, 1997 pp. 427-436.

PLA BALLESTER, E. (1969): "Notas sobre economía antigua del P. Valenciano. Instrumentos metálicos" X Congreso Nacional de Arqueologia, Zaragoza, pp. 143-190.

PONTE, S. (1978): "Instrumentos de fraçao, tecelagem e costura de Conímbriga" Conímbriga, vol. XVII.

QUEROL, Ma A. (1999): “QQué enseñamos?. Consideraciones previas a la conservación y difusión de yacimientos arqueológicos", XXVX C.N.A., Valencia, p. 13-20. Valencia.

RAMOS SAINZ, Mª L. (1992): "Una piscina bautismal de planta cruciforme descubierta en la villa romana de El Saucedo (Talavera de la Reina, Toledo)", III Reunió d' Arqueología Cristiana Hispánica, 105-110 (Maó, 1988).

RAMOS M M. y CASTELO R., (1992): "Excavaciones en la villa romana de Saucedo. Últimos avances con relación al hallazgo de una basílica paleocristiana", II Jornadas de Arqueología de Talavera de la Reina y su entorno, pp. 115-125. Toledo.

RAMOS Mª.L., y DURÁN R.M. (1988): "La villa romana de Saucedo (Talavera de la Reina, Toledo). Aportaciones a su estudio en relación con la implantación de villas romanas en la vega del Tajo", Actas del I Congreso de Historia de Castilla-La Mancha, IV, Romanos y Visigodos, pp. 237-242. Toledo. 
RODRÍGUEZ MARTÍN, F.G. (1995): "La villa romana de Torre-Águila, Barbaño-Montijo, Badajoz", J.R.A. 8., p. 313-316.

RUIZ MOLINA, L. (1998): "El poblamiento romano en el área de Yecla (Murcia)", Arte y poblamiento en el SE peninsular Antigüedad y Cristianismo, V, 565-598. Murcia.

RUIZ, A. et alii (1999); "El seguimiento de una intervención arqueológica: el caso de Marroquíes Bajos en Jaén”, XXV C.N.A., Valencia, pp. 407-419. Valencia.

SASSE, B., CASTELO, R., RAMOS, Mª.L. (1995a): "Placa de cinturón múltiple hispano-visigoda hallada en la villa de El Saucedo (Talavera la Nueva, Toledo)" XXIII Congreso Nacional de Arqueologia, Elche, pp.365-378.

SASSE, B., CASTELO, R., RAMOS, M².L. (1995b): "Las placas de cinturón múltiple hispano-visigodas: a propósito de la hallada en El Saucedo (Talavera la Nueva, Toledo)" AEspA, 68, pp. 165-187. Madrid.

SERRA RÁFOLS, J. de C. (1952): La villa romana de la Debesa de la Cocosa, Badajoz. Badajoz.

TARACENA, B. Y VÁZQUEZ DE PARGA, L. (1946): "Excavaciones en Navarra. La romanización”, Príncipe de Viana, VII, pp. 415-407. Pamplona.

TARACENA, B. Y VÁZQUEZ DE PARGA, L. (1956): "Excavaciones del Ramalete", Excavaciones en Navarra, vol. II (1947-1951), 3-40. Pamplona.

TORRECILla AZNAR, A. (e.p.a): "Los vidrios romanos de la villa de "El Saucedo" (Talavera la Nueva, Toledo)", III C.A.P., Vila Real, sept. de 1999.

TORRECILLA AZNAR, A. (e.p.b): "Los vidrios romanos de la villa de El Saucedo (Talavera la Nueva, Toledo)", I Jornadas de Arqueología Romana de Talavera "Hércules 2000", Talavera de la Reina (Toledo), 23-25 de noviembre de 2000.

TORRECILLA AZNAR, A., (1999): "Materiales de construcción en las termas de la Hispania romana. A propósito de los materiales hallados en la villa de "El Saucedo" (Talavera la Nueva, Toledo)", XXIV Congreso Nacional de Arqueología, octubre 1997, 397-416. Cartagena.

TORRECILlA, A., CASTELO, R., ARRIBAS, R., PANIZO, I., LÓPEZ, A., (1999): "Los pavimentos musivarios de la villa de El Saucedo (Talavera la Nueva, Toledo)", XXIV Congreso Nacional de Arqueología, (Cartagena, 1997), 435-455, Cartagena.

URBINA, D. et alii (2001): "Plaza de Moros (Villatobas, Toledo). Un yacimiento arqueológico como recurso educativo", Boletin del Ilustre Colegio de Doctores y Licenciados en Filosofia y Letras y Ciencias, Colegio Profesional de Educación, $n^{\circ} 121$, pp. 32-34. 